\title{
An Analysis of Hardwood Log Grading Systems in the Appalachian Region
}

Jordan Russell Thompson

WVU, jthompson@nwtf.net

Follow this and additional works at: https://researchrepository.wvu.edu/etd

Part of the Wood Science and Pulp, Paper Technology Commons

\section{Recommended Citation}

Thompson, Jordan Russell, "An Analysis of Hardwood Log Grading Systems in the Appalachian Region" (2019). Graduate Theses, Dissertations, and Problem Reports. 7475.

https://researchrepository.wvu.edu/etd/7475

This Thesis is protected by copyright and/or related rights. It has been brought to you by the The Research Repository @ WVU with permission from the rights-holder(s). You are free to use this Thesis in any way that is permitted by the copyright and related rights legislation that applies to your use. For other uses you must obtain permission from the rights-holder(s) directly, unless additional rights are indicated by a Creative Commons license in the record and/ or on the work itself. This Thesis has been accepted for inclusion in WVU Graduate Theses, Dissertations, and Problem Reports collection by an authorized administrator of The Research Repository @ WVU. For more information, please contact researchrepository@mail.wvu.edu. 
An Analysis of Hardwood Log Grading Systems in the Appalachian Region

Jordan R. Thompson

West Virginia University Division of Forestry \& Natural Resources,

Appalachian Hardwood Center

Thesis submitted to the Davis College of Agriculture, Natural Resources, and Design at West Virginia University in partial fulfillment of the requirements

for the degree of

Master of Sciences

in

Forestry

Joseph McNeel, PhD, Committee Chairperson

Curt Hassler, PhD

Shawn Grushecky, PhD

Division of Forestry and Natural Resources

Morgantown, West Virginia

2019

Keywords: Log Grading, Log Scaling, Raw Material Purchase, Production, Primary

Wood Product Producers

Copyright 2019 Jordan Thompson 


\section{$\underline{\text { Abstract }}$ \\ An Analysis of Hardwood Log Grading Systems in the Appalachian Region Jordan R. Thompson}

This study identifies and describes various hardwood log grading systems historically used by the hardwood industry in the United States through a comprehensive literature review and analysis. Additionally, an industry sector survey (Appendix A) was designed and conducted to identify current log hardwood grading systems. Finally, based on the survey data, an analysis of the practices and techniques currently used for scaling and grading Appalachian hardwood logs is presented and discussed.

In the first component of the study, books, journal articles, and papers pertaining to log grading are sorted and broached chronologically by the publication date and then separated into three chronological categories and review. Short summary abstracts of these studies are presented to briefly describe key findings of that study.

In the second phase of the study, the results of a focused survey of hardwood sawmills, log yards, and other wood product producers in the Appalachian region is presented to profile current hardwood log grading and scaling practices. The survey consists of 18 major questions and eight sub-questions designed to characterize current scaling and grading practices used by the forest products industry in Appalachia (Appendix A). Survey results are summarized and analyzed to produce a statistical analysis of the current grading systems used by responding wood product producers. The results will be used to identify the commonly used hardwood log grading and scaling practices. Information developed from this study could be used as a means for the identification of barriers within the industry to a standardized log grading and scaling system. Ultimately, once the barriers are identified and addressed, the data could be used to develop scaling and grading protocols for anew hardwood log grading and system. 


\section{$\underline{\text { Acknowledgements }}$}

I would like to thank all the faculty members involved in this project; it has been extremely challenging but a rewarding process. I would also like to thank all my family members and friend who supported and cheered me on. I would like to dedicate this thesis to my Mother Lisa Thompson and my Father H. Dewey Thompson thanks for all the help, I couldn't have done it with out you!

- Jordan Thompson. 


\section{Table of Contents}

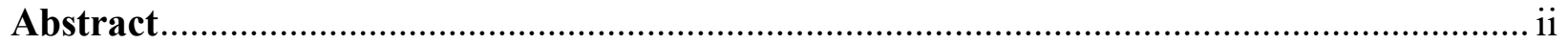

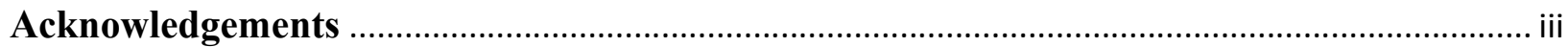

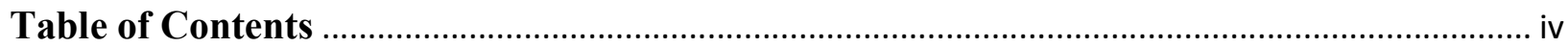

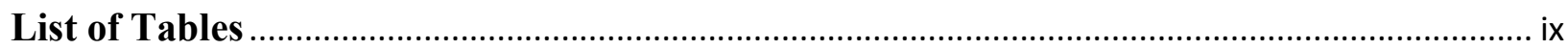

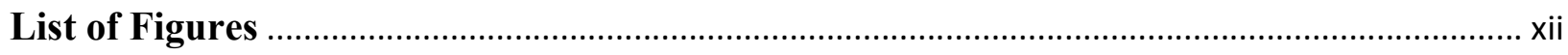

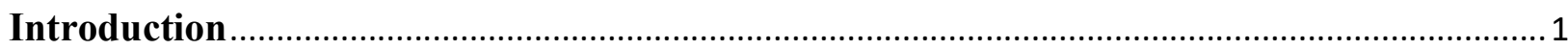

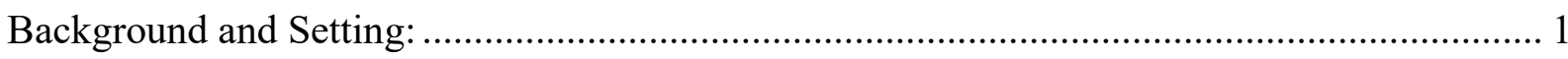

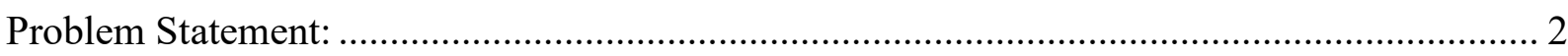

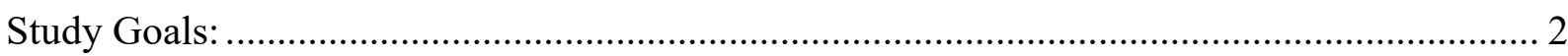

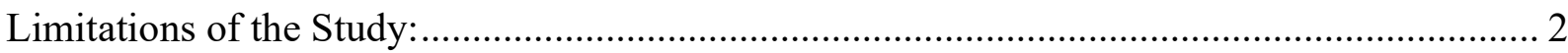

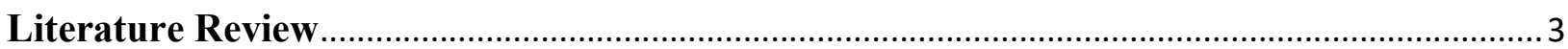

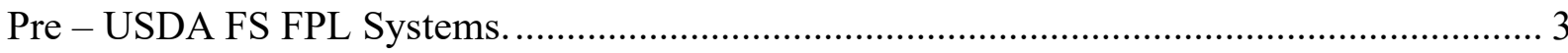

United States Department of Agriculture Forest Service - Forest Products Laboratory

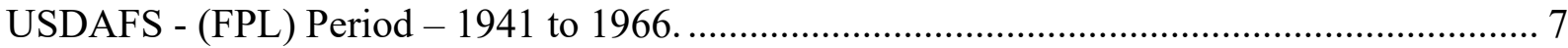

Other Log Grading Systems During the USDA FS FPL Timeframe 1948-1965.................. 16

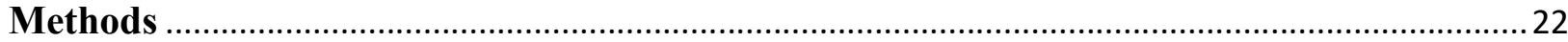

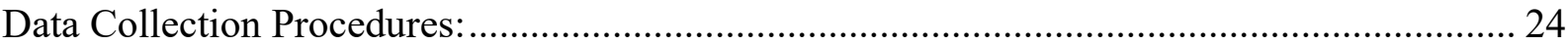

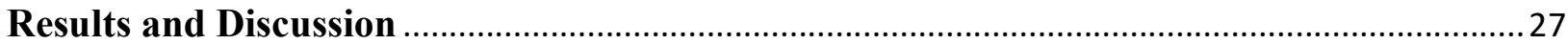

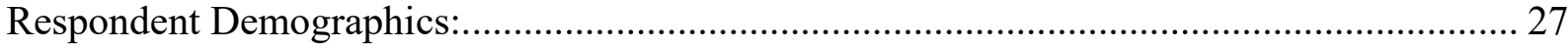

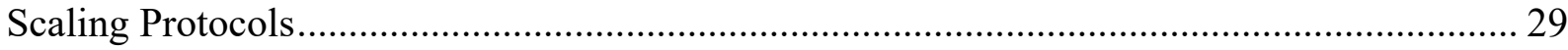

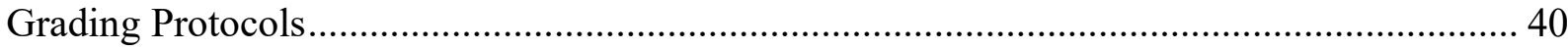

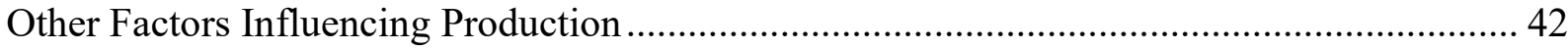

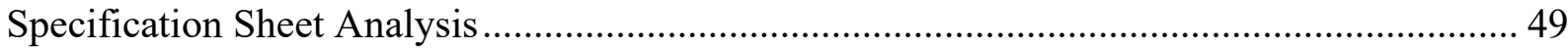

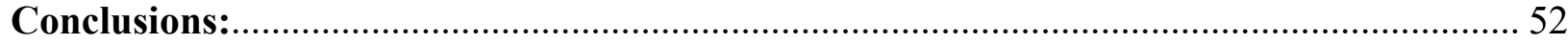

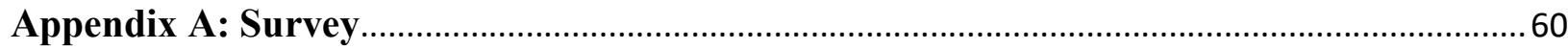

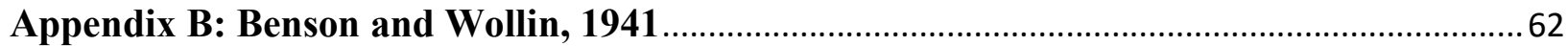

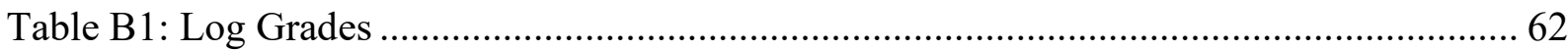

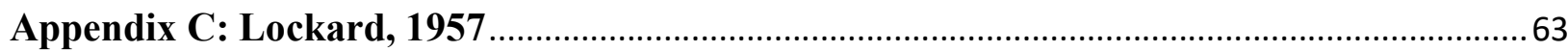

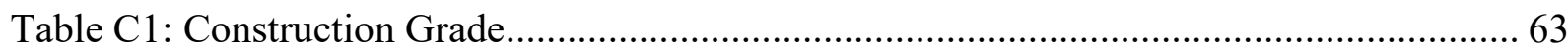

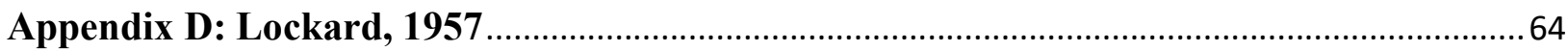

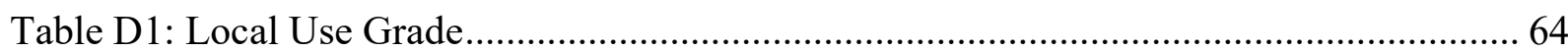

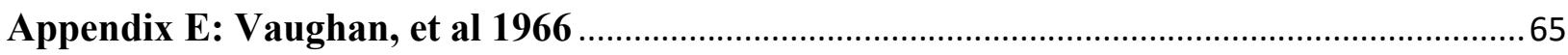

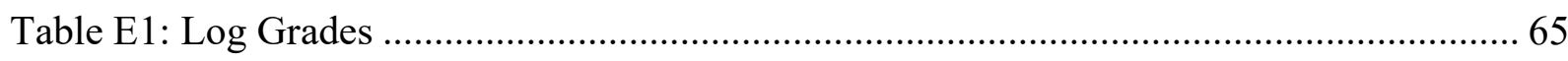




\section{$\underline{\text { List of Tables }}$}

Table 1. Geographic distribution of useable survey responses to the survey on grading and scaling hardwood sawlogs in the Appalachian region.

Table 2. Annual production levels (in million board feet) for all useable survey respondents. ... 28

Table 3. Number of primary wood product producers in KY, MD, NC, NY, OH, PA, TN, VA, and WV separated by annual production level.

Table 4. Number of primary wood product producers in KY, MD, NC, NY, OH, PA, TN, VA, and WV separated by annual production level and log rule used to determine log volume.....

Table 5. Do mills purchase even length logs or both even and odd length logs, by annual production level in the Appalachian region?

Table 6. How do mills determine scaling diameter, by annual production level in the Appalachian region?

Table 7. How do mills handle fractional proportions of diameter, by annual production level in the Appalachian region?

Table 8 . How primary wood product producers handle the measurement of double hearts by annual production level in the Appalachian region.

Table 9. Do primary wood product producers pay differently for butt logs than uppers by annual production level in the Appalachian region?

Table 10. How primary wood product producers handle sweep deductions by annual production level in the Appalachian region.

Table 11. How primary wood product producers handle hole/interior defect deductions by annual production level in the Appalachian region.

Table 12 . How primary wood product producers handle shake deductions by annual production level in the Appalachian region.

Table 13. Primary wood producers preferred trim allowance by annual production level in the Appalachian region. 
Table 14. Primary wood product producers minimum trim allowance by annual production level for the Appalachian region.

Table 15. Do primary wood product producers grade logs as they lay by production level in the Appalachian region?

Table 16. Assumption made about the down side of the log when grading hardwood sawlogs by annual production level for primary wood product producers in the Appalachian region. 42

Table 17. Would primary wood product producers support an industry standard by annual production level for the Appalachian region.

Table 18. Do primary wood product producers purchase gate wood by production level in the Appalachian region?

Table 19. Primary wood product producers annual supply of gatewood by production level in the Appalachian region.

Table 20. Do primary wood product producers grade logs from their own stumpage tracts by production level in the Appalachian region.

Table 21. Do primary wood product producers buy tree length stems by production level in the Appalachian region.

Table 22. Primary wood product producers supply of tree length stems by production level in the Appalachian region.

Table 23. Do primary wood product producers have difficulty getting long length logs by production level in the Appalachian region?

Table 24. Are primary wood product producers paying premiums for longer length logs by production level in the Appalachian region?

Table 25. Do primary wood product producers provide straight through pricing by production level in the Appalachian region.

Table 26. Do primary wood product producers know the cost to run the mill per hour by production level in the Appalachian region? 
Table 27. Do primary wood product producers know the sawing cost per mbf by species by production level in the Appalachian region?

Table 28. Do primary wood product producers know the cost to run the mill per hour and the sawing cost per mbf by species delineated by production level in the Appalachian region?

Table 29. Do primary wood product producers have publicly available log grading standards by annual production level for the Appalachian region....

Table 30. Distribution of the highest log grade across scaling diameter and clear faces, based on specification sheets provided by survey respondents from primary wood product producers in the Appalachian region $(\mathrm{N}=26)$.

Table 31. Distribution of the second highest log grade across scaling diameter and clear faces, based on specification sheets provide by survey respondent from primary wood product producers in the Appalachian region $(\mathrm{N}=26)$. 


\section{List of Figures}

Figure 1. Flowchart of this research effort to identify current log grading systems and to provide

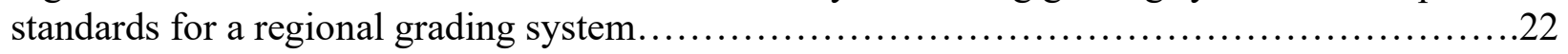

Figure 2. Double hearts in hardwood logs (Anonymous, p. 23, 2001)...................... 35

Figure 3. A diagram of sweep and holes in hardwood logs (Rast, E.D., Sonderman, D.L.,

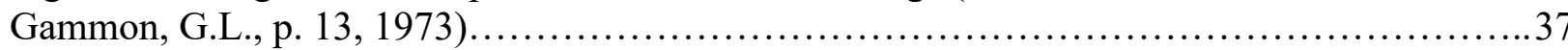

Figure 4. A diagram of shake and holes in hardwood logs (Rast, E.D., et al., p. 19, 1973)......37 


\section{Background and Setting}

\section{Introduction}

Hardwood log grading systems have lacked consistency for many years due to the subjectivity associated with scaling and grading hardwood logs. Over the last century, many grading systems have been created to standardize the process, but with little success.

Only one hardwood log grading system was standardized through the efforts of the United States Department of Agriculture Forest Service Forest Products Laboratory (USDA FS FPL). This system of log grading was developed between the early 1940's through the late 1960's and has received very little attention outside the USDA FS since that time. The USDA FS FPL hardwood grading system was never really accepted by the forest products industry and was generally used only by the United States Department of Agriculture Forest Service (USDA FS) (Hassler, et al., 2019).

The USDA FS FPL hardwood log grading system operates on a platform similar to the way a lumber grader would grade a piece of lumber. The log is separated into 4 equal sections commonly referred to as faces. These faces are then graded based on defect free areas that are contained within the grading area. The log grade is then based on the second worst face.

Due to the lack of an acceptable standardized hardwood log grading system, hardwood using mills have developed alternative and proprietary systems for grading hardwood saw logs. These systems assign a unique, proprietary grade to a log based predominantly on key external features visible to the grader. Many of these systems are based on a "rule of thumb" set of deduction protocols for scaling. Most grading systems currently in use base the assigned log grade on $\log$ size combined with an estimate of the number of clear faces present on the $\log$. Many wood product producers have no information regarding the effectiveness of these proprietary systems, other than estimates of mill profitability over time.

Log grades, combined with volume estimates obtained from log rules, are used to ascribe some estimate of the quality on individual hardwood saw logs. Log grades and log rules are many times confused by the industry. A log rule is a volume function developed to project the quantity of lumber within a log expressed in board feet (Freese, 1973). Scaling hardwood logs is the act of measuring the small end diameter inside bark and the total length. Measurement with scaling diameter and log length, the board footage in a log can be determined using the log rule. A $\log$ grade is a set of rules used to determine the quality of the log. 


\section{$\underline{\text { Problem Statement }}$}

The USDA FS FPL hardwood grading system was never really accepted by the forest products industry and was generally used only by USDA FS foresters and contractors working with the USDA FS (Hassler, et al., 2019). Over the past 100 years or more, forest product companies have created individual proprietary hardwood log grading systems tailored to their specific needs and interests in the process of purchasing logs.

Additionally, it is not clear what other types of grading systems exist for use in the Appalachian region or for hardwood logs in general. This study was designed to explore the characteristics of current industry log grading and scaling systems to better understand the complexities and identify common features among all documented systems that are applicable to this effort.

Typically, these "home-made" proprietary grading systems are simple to use and distinctly differentiate between low and high value logs from the perspective of the individual mill. But, as a result, every wood product producer is purchasing logs on a different platform which makes consistent grading and pricing difficult, if not impossible, from a log seller's perspective.

\section{$\underline{\text { Study Goals }}$}

The study was built around the following three goals:

1. Describe and detail the common characteristics of hardwood log grading systems historically available to the hardwood industry through a comprehensive literature review.

2. Profile current hardwood log grading and scaling systems used by the hardwood forest industry.

3. Characterize standard scaling and grading protocols for a theoretical system that could be used based on a sawmill's level of annual production in the Appalachian hardwood region.

\section{Limitations of the Study}

This study focuses only on hardwood sawlog grading systems from the Appalachian Region of the United States. While the study may find significant commonalities among these systems, the standards cannot necessarily be applied to hardwood logs from other regions of the United States. Furthermore, in many instances wood product producers are reluctant to disclose 
how they assess their raw material quality, which could cause some transparency issues with how logs are graded and valued.

\section{$\underline{\text { Literature Review }}$}

This literature review is focused on the history of hardwood log grading systems introduced in the United States since the start of the $20^{\text {th }}$ century. This review of log grading systems is separated chronologically into three periods: Pre -United States Department of Agriculture Forest Service Forest Products Laboratory (USDA FS FPL) system, the USDA FS FPL system and associated variations, and other log grading systems during the USDA FS FPL time frame. Each identified system was evaluated using the following nine criteria:

1. Literature Citation.

2. Date first introduced.

3. Log grades.

4. Scaling system.

5. Lumber grades considered.

6. Impact of defects.

7. Grades based on empirical data or theoretical in nature.

8. Applicable regions.

9. Presence of special rules.

\section{Pre - USDA FS FPL Systems.}

The material reviewed in this section ranges chronologically from the turn of the $20^{\text {th }}$ century to approximately 1941. Six documents pertaining to log grading were identified from this period, with two publications containing unique log grading systems. The authors presenting these systems discuss four to six distinct log grades, all using different log rules, and working from either theoretical or empirical data.

\section{Forest Mensuration (Graves, 1906)}

Graves suggests that grade-based log rules help define the volume and grade of lumber contained in individual logs. He mentions graded log rule tables developed by the USDA Forest Service (USDA FS) and suggests these tables could greatly improve the grading of logs for value (Graves, 1906). Unfortunately, the tables mentioned by Graves never appeared in any 
subsequent articles and were quite probably never published. Therefore, it is not possible to characterize this reference according to the nine criteria noted earlier.

\section{The Principles and General Methods of Operation in the United States (Bryant, 1913)}

Bryant describes a log grading system in his 1913 text. The system details six log grades and uses the Spaulding log rule (Freese, 1973) to determine volume. He also describes six unique defects that affect grade. The system does not consider any lumber grade in defining log grades.

1. Literature Citation:

Bryant, C. B. 1913. Logging - The Principles and General Methods of Operation in the United States. John Wiley \& Sons, New York, NY. 547 p.

2. Date first introduced: 1913.

3. Log grades: This system contains six distinct log grades that are differentiated by diameter and the presence or absence of knots.

4. Scaling system: Spaulding log rule (Freese, 1973).

5. Lumber grades considered: No information exists on what lumber grade(s) the log grades are based on.

6. Impact of defects: Seven unique defects are noted by the author, including hollow, old, trapper, edged, crotch or forked, crooked, and cull logs (citation, p. 526).

7. Grades based on: Probably theoretical, no evidence exists that the grades were determined from empirical data.

8. Applicable regions: None specified.

9. Presence of special rules: None specified.

\section{Forest Mensuration (Chapman, 1921)}

Chapman states that logs are normally evaluated based on a system comprised of three $\log$ grades designed to stratify the quality of lumber contained inside of the log to ensure the logs fall into a particular grade category. He implies log grading systems should be kept very general to ensure that price adjustment can be easily applied (Chapman, 1921). Beyond these simple 
statements, no log grades or log grading systems were ever defined or presented in Chapman's book.

\section{Lumber and Log Grades for Southern Hardwoods (Garver and Miller, 1933)}

Garver and Miller present a system where log grades were developed based on results from eight (8) different lumber yield mill studies. Their log grading system is the first identified in this review to use empirical data to define log grades. The system defines four log grades; identified as 1, 2, 3, and 4 and uses the Scribner Decimal C log rule to determine log volume. The system defines seven unique defects that affect volume and grade. Furthermore, the intended region for use is defined as the Southern United States.

1. Literature Citation:

Garver, R. D., and Raymond H. Miller. 1933. Lumber and Log Grades for Southern Hardwoods. Madison, WI: U.S. Dept. of Agriculture, Forest Service, Forest Products Laboratory. $19 \mathrm{pp}$.

2. Date first introduced: 1933.

3. Log grades: The system contains four distinct log grades differentiated by diameter inside bark and number of standard defects (citation, p. 5-6).

4. Scaling system: Scribner Decimal C log rule.

5. Lumber grade considered: Grades are based on yield of No. 1 Common and FAS lumber.

6. Impact of defects: Six unique defects are noted by the author, including sound knots, grub holes, worm holes, bird peck, bark pockets, and sweep (citation, p. 6).

7. Grades based on: Empirical data collected from eight (8) mill studies.

8. Applicable regions: Southern United States.

9. Presence of special rules: None specified.

\section{Grading Hardwood Logs (Benson and Wollin, 1938)}

Benson and Wollin worked together on the New England timber salvage effort following the New England hurricane of 1938, and eventually went on to develop the standard USDA FS FPL log grading system. This system has become the only nationally recognized log grading system in the United States, is utilized primarily by the research industry, and has been the primary system used to teach $\log$ grading at the university level. 
This is the first publicly documented collaboration on log grading by Benson and Wollin. Furthermore, this publication provides details on the status of hardwood log grading in the US in 1938. In the report, the authors note that the hardwood region did not use well defined systems like those already established in the western United States. Finally, they indicate there was no defined tie between $\log$ and lumber defects in hardwood log grading systems up to 1938 . The only reference to log grades is their acknowledgement of three grades; 1,2 , and 3 . The authors provide no reference to the characteristics or features of $\operatorname{logs}$ that fall into those quality classes, nor do they provide details on any specific log grading systems so that is was not possible to classify this effort according to the nine criteria.

\section{Report of the U.S Forest Service Programs Resulting from The New England Hurricane (Anonymous, 1943)}

This report, Forest Service Programs Resulting from The New England Hurricane Timber Salvage (Anonymous, 1943), provides an update on the salvage work that resulted from the 1938 hurricane event in New England. The report details a log grading system that was used to merchandize downed hardwood timber that fell or was damaged as a result of the hurricane. It was originally developed only for Eastern White pine, as detailed in a 1938 report developed by the USDA FS FPL (Anonymous, 1938).

The revised grading system presented in the 1943 report includes a set of hardwood log grades. These log grades encompassed a larger species mix and grouped species into specific categories. At least 16 hardwood species were defined for the system, with the more commercially valuable species including white oak, red oak, and black cherry. These hardwood log grades probably formed the basis of the USDA FS FPL log grading system.

The report also notes that Benson and Wollin were detailed to this effort from the USDA FS FPL to assist with the timber salvage. The clear connection between Benson and Wollin in this effort and their strong connection with hardwood log grading suggests that the New England hurricane may have, in fact, spawned the creation of the USDA FS FPL log grading system.

The system described in the report details three hardwood log grades and uses the International $1 / 4$ inch $\log$ rule to determine volume. The authors detailed two distinct defects that affect grade. Additionally, the system has no ties to any type of lumber grades associated with log grades. 
1. Literature Citation:

Anonymous: Report of The U. S. Forest Service Programs Resulting from The New England Hurricane of September 21, 1943. Northeastern Timber Salvage Administration. February 1943. Boston, Mass. 594 p.

2. Date first introduced: 1943

3. Log grades: This system contains three distinct log grades that are differentiated by inside bark diameter, length, total defect permitted and surface requirements (citation, p. 329).

4. Scaling system: International $1 / 4$ inch $\log$ rule.

5. Lumber grades considered: No lumber grades were considered.

6. Impact of defects: Two unique defects noted by the author, including insect damage and stain (citation, p. 330).

7. Grades based on: Probably theoretical, no evidence exists that the grades were determined from empirical data.

8. Applicable regions: New England.

9. Presence of special rules: The system has five distinct special rules encompassing;

Unmerchantable - three log length and cull percentage rules (citation, p. 329).

Variations for Species - two diameter deductions rules (citation, p. 329).

\section{United States Department of Agriculture Forest Service - Forest Products Laboratory USDAFS - (FPL) Period - 1941 to 1966.}

This era focuses on the development of the USDA FS FPL log grading system over a 25year period. Changes in the USDA FS FPL log grading system are defined in this section through specific literature citations. Where appropriate the USDA FS FPL log grading systems will be referenced and presented in the appendix. The nine criteria noted at the beginning of this section are used throughout this section to note any other changes in the USDA FS FPL log grading system.

\section{Something New in Hardwood Log Grades (Benson, A.O. 1941)}

Benson provides information on the data used to develop the USDA FS FPL log grading system. He states that the new log grading system contains data from 7,000 logs and 20 different species produced through a field study inventory and lumber tallies for individual logs. From 
the data, rudimentary log grades are suggested; No. 1 grade would admit few or no defects; No. 2 grade would admit more defects; and No. 3 grade still more defects.

No actual information is provided on the specifications of how the log grades are applied. Two major components of the system are revealed, however. First, logs are separated into four quadrants, or faces, for grading and second, these faces are evaluated independently of each other, much like grading a piece of lumber.

\section{Grading Northern Hardwood Logs (Benson and Wollin, 1941)}

In November 1941, the log grading system developed by Benson and Wollin, including rules and specifications for grading hardwood logs, fully emerged. The system defines four log grades; 1, 2, 3, and 3A. It allows for the use of any log rule agreed on by buyer and seller to determine log volume. The intended region for use is defined as Eastern United States and the Lake States (Appendix B).

1. Literature Citation:

Benson, A.O. and A. C. Wollin. 1941. Grading northern hardwood logs. US Dept. Agriculture Forest Service Report. November 1941 34pp.

2. Date first introduced: November 1941.

3. Log grades: The system contains four distinct log grades that are differentiated by diameter inside bark, log length, cull permitted, sweep permitted, and surface requirements (Appendix B Table 1: Log Grades).

4. Scaling system: The log rule used to estimate volume will be determined by an agreement between the buyer and seller.

5. Lumber grades considered: Grades are based on yield of National Hardwood Lumber Association (NHLA) No. 1 Common or better lumber.

6. Impact of defects: None specified. The citation does not define what constitutes disqualification of a cutting.

7. Grades are based on: Empirical data from a data base of 7,000 logs and 20 different species.

8. Applicable regions: Eastern United States and the Lake States.

9. Presence of special rules: None specified. 


\section{Sawlog Grades for Hardwoods (Wollin and Vaughan, 1947)}

In 1947, Wollin and Vaughan attempted to promote industry acceptance of the newly introduced hardwood log grading system by introducing additional grades and quality classifications. To gain a broader use of the system by the industry, the authors added requirements for what they termed were "satisfactory" log grades:

1. Be able to segregate logs into high, medium and low-quality groups according to the grade yields and value of the lumber produced,

2. Complement standard methods for appraising and evaluating timber where large volumes are involved and errors associated with individual logs average themselves out,

3. Be applicable to relatively small lots of logs where balancing errors with respect to individual logs cannot be relied upon,

4. Classify logs based on similar lumber grade yields, so that any one grade is made up of logs having a fixed range of quality with as little overlap among grades as possible,

5. Apply to all species that are covered by the lumber grading system that is used and reflect the characteristics of the individual species and their effect on grade yields,

6. Make use of the same terms and methods of measurement that users would be accustomed to (Wollin \& Vaughan, 1947, p.2).

In addition to these developments the system had additional variables added to the grading parameters and the following changes in the grades; diameter limits, length requirements, clear cutting requirements, cull deduction, and sound end defects. The system details three log grades and uses any log rule agreed upon by the buyer and seller to determine volume. The log grades are based on yield of NHLA No. 1 Common or better lumber. The system also details fourteen defects with ten affecting grade. The four defects that do not affect grade are adventitious buds, bird peck, bumps, and sound knots, Furthermore, the system has eight special grading rules. The primary geographical region for application is the Eastern United States and the Lake States.

1. Literature Citation

Wollin, A. C. and C. L. Vaughan. 1947. Sawlog Grades for Hardwoods Central States Studies. USFS Forest Products Lab, Madison, WI, No. D1699. $22 \mathrm{pp}$. 
2. Date first introduced: 1947.

3. Log grades: The system contains three distinct log grades differentiated by diameter inside bark, length, clear cuttings, sweep, crook, cull deduction and sound end defects (citation, p. 6). There were also changes in log grades as follows:

a) Log diameter changes in grade No. 1 butts only to 13 inches - 15 inches, Butts and uppers 16"-19 inches, and 20+ inches, No. 2 Butts and upper 11+ inches.

b) Length in log grade No. 2 changed to 8 feet $-12+$ feet.

c) Clear cuttings on best 3 faces is now 4/6 in log grade No. 2 .

d) Cull deduction of $67 \%$ is allowed in grade 3 .

e) An addition of sound end defects of $50 \%$ for grades $1 \& 2$ in grade, and in grade 3 it is unlimited.

4. Scaling system used: Whatever log rule the buyer or seller have agreed to.

5. Lumber grades considered: Grades are based on yield of NHLA No. 1 common or better.

6. Impact of defects: Seventeen unique defects noted by the author:

a) Deductible defects - sweep, crook, rot, shake, heart checks, fire damage, flutes, mechanical damage, grub holes.

b) Non-deductible defects - adventitious buds, bird peck, sound knots, over-grown knots, burls, bumps, and cat faces (citation, p. 20).

7. Grades based on: Empirical data from 14 mill studies comprised of 2,886 logs over a range of 15 species.

8. Applicable regions: Eastern United States and the Lake States.

9. Presence of special rules: The system has seven distinct special rules and one definition section encompassing specific species, minimum diameters, faces and cuttings, required yields, sweep, and cull (citation, p. 6).

\section{Hardwood Log Grades and Standard Lumber - Proposals and Results (Wollin and Vaughan, 1949)}

In 1949, Wollin and Vaughan released Hardwood Log Grades for Standard Lumber Proposals and Results. In general, this is the same grading system that was previously presented 
in Wollin and Vaughan's 1947 publication, Sawlog Grades for Hardwoods, but focused on strengthening the grading rules for grade 3 logs.

1. Literature Citation:

Wollin, A. C. and C. L. Vaughan. 1949. Hardwood Log Grades and Standard Lumber - Proposals and Results. USDA Forest Service, Forest Products Lab, D1737. $15 \mathrm{p}$.

2. Date first introduced: 1949.

3. Log grades: The system contains three distinct log grades differentiated by diameter inside bark, length, clear cuttings, sweep, crook, cull deduction and sound end defects (citation, p. 4). Several changes were also made for log grades, including:

a) Instructions not listed in the table were provided for sound end defects.

b) Clear cutting length was defined as 2 feet for log grade 3 .

c) The number of clear cutting lengths was defined as unlimited for log grade 3 .

d) Total clear cutting yield in face length was adjusted to $3 / 6$ (or 50 percent) for $\log$ grade 3.

e) Sweep and crook deduction was adjusted to 50 percent of the volume for log grade 3.

f) Cull deduction was adjusted to $50 \%$ of the volume for $\log$ grade 3 .

4. Scaling system used: Whatever log rule the buyer or seller have agreed to.

5. Lumber grades considered: Grades based on yield of NHLA No. 1 Common or better lumber.

6. Impact of defects: Seven unique defects were added by the authors, including: decay, shake, worm holes, mineral stain, bark pockets, frost seams and cracks.

7. Grades based on: Empirical data from 11,000 logs sawn at 28 sawmills.

8. Applicable regions: Eastern United States and Lake States.

9. Presence of special rules: The system has seven distinct special rules encompassing specific species, minimum diameters, faces and cuttings, required yields, sweep, and cull deductions (citation, p. 4). 
Manual for Hardwood Log Grading in the Northeast (Preliminary edition) (Lockard, C.R. 1957)

The intent of this report was to help with the interpretation of the log grades, how to apply them, and to define certain log classes not covered in previous log grading publications produced by the USDA FS FPL (Lockard, 1957). The construction and local use log grades were added to augment the purchase of low-quality hardwood logs at mills. Other changes included: Renaming the log grades, how sweep allowance is handled, diameter limits within grades, and clear cutting lengths (Appendix C\&D).

1. Literature Citation:

Lockard, C.R. 1957. Manual for hardwood log grading in the northeast (Preliminary edition). Northeastern Forest Experimental Station Forest Service, U.S. Dept. Agri. Upper Darby, PA. 41 pp.

2. Date first introduced: 1957.

3. Log grades: The system contains three distinct log grades that are differentiated by log position in tree, diameter inside bark, length, clear cuttings, sweep, and cull allowance (citation, p. 9). With an addition of the new construction and local use log grades (Appendix C: Table 1: Construction Grade \& Appendix D: Table 2: Local Use Grade). There were also changes in factory lumber log grades as follows:

a) The log grades are now named F1, F2, and F3

b) Sweep allowance is now separated into two categories, (1) logs with less than $1 / 4$ of end in sound defects where deductions are F1-15\%, F2-30\% and F3-50\% and (2) $\operatorname{logs}$ with more than $1 / 4$ of end in sound defects where deductions are F1-10\%, F2-20\% and F3-35\%.

c) Scaling diameter for F2 butts and uppers is now 11 inches + and 12 inches +

d) Length without trim for F2 now has four divisions 10 feet +, 8-9 feet, 10-11 feet, and 12 feet + .

e) Clear cuttings for F2 is now 3 feet for all four diameter classes.

f) Required length of cuttings for F2 is now 2 feet, 2 feet, 2 feet, and 3 feet and for F3 no limit.

g) Clear cuttings required for total length for $\mathrm{F} 2 \log$ length is now $2 / 3,3 / 4,2 / 3$, and $2 / 3$ and for F3 1/2. 
4. Scaling system: Scribner, International, or Doyle log rule; this is the first time a specified scaling system is mentioned.

5. Lumber grades considered: Grades are based on yield of NHLA No. 1 Common or better lumber.

6. Impact of defects: Fifteen unique defects are added by the author, including bulges, bumps, butt scars, conk, canker, flange, fork, holes, limbs, wounds, splits, double pith, dote, grease spots, and spider heart (citation, p. 9).

7. Grades are based on: Empirical data from 11,000 logs sawn at 28 sawmills.

8. Applicable regions: Eastern United States and Lake States.

9. Presence of special rules: The system has four distinct special rules and two instructions encompassing specific species, minimum diameters, and cull deductions (citation, p. 9).

\section{Hardwood Log Grades and Standard Lumber-Proposals and Results; Information Reviewed and Reaffirmed (Wollin., A.C. and C.L. Vaughan. 1959)}

In this publication no changes to the log grades occurred. Wollin and Vaughan did, however, publish the results of the mill study data gathered from 11,000 logs sawn at 28 sawmills with 19 species classifications. These findings are broken down first by the species and then by yield of graded lumber and log diameter.

1. Literature Citation

Wollin, A. C. and C. L. Vaughan. 1959. Hardwood Log Grades and Standard Lumber - Proposals and Results (Information Reviewed and Reaffirmed). USDA Forest Service, Forest Products Lab, D1737. 15pp.

2. Date first introduced: 1959.

3. - 9. Same as Wollin and Vaughan (1949).

\section{How to Evaluate the Quality of Hardwood Logs for Factory Lumber (Petro, F.J., 1962)}

Petro detailed a variation of the Benson and Wollin (1959) grading system in his 1962 text. The revised system was created to test the possibility of adopting the system for use in Canada. The system generally remains the same except for two relatively small variations, only one of which actually affects the log grades, by changing the clear-cutting yields to a format in which they are noted in total yield ratings out of 12 possible on the best 3 grading faces. This is 
different from previous variations of the system where the clear cutting are based in total yield ratings of 6 on the best 3 grading faces. The log scaling systems noted for use are International 1/4-inch and Doyle log rules.

1. Literature Citation:

Petro, F.J. 1962. How to Evaluate the Quality of Hardwood Logs for Factory Lumber. Forest Products Research Branch, Ottawa Laboratory, Ottawa, Canada. Technical Note No. 34. 33pp.

2. Date when first introduced: 1962.

3. Log grades: The system contains three distinct log grades that are differentiated by log position in tree, diameter inside bark, length, clear cuttings, sweep, crook, and cull deduction (citation, p. 16). There were also changes in log grades as follows:

a) Grades defined as 1, 2, and 3 as opposed to F1, F2, and F3.

b) Clear cuttings yield - the yields are now noted as grade $1-10 / 12$, grade $2-8 / 12$ and 9/12, and grade $3-6 / 12$.

4. Scaling system: International $1 / 4$ inch or Doyle log rule.

5. Lumber grades considered: Grades are based on yield of NHLA No. 1 Common or better lumber.

6. Impact of defects: Same as (Benson \& Wollin, 1959).

7. Grades based on: Empirical data from 11,000 logs sawed at 28 sawmills in the Northern and Appalachian regions.

8. Applicable regions: Northern and Central hardwood regions.

9. Presence of special rules: The system has four distinct special rules same as Lockard (1957) encompassing specific species, minimum diameters, cull deductions and one instruction (citation, p. 16).

\section{A Guide to Hardwood Log Grading (Anonymous 1965)}

This publication details the same log grading system produced by Lockard in his text from 1957. Additionally, the author details the local and construction use grading systems with a few changes dealing with unsound defects and total cull allowable.

1. Literature Citation: 
USDA Forest Service. 1965. A Guide to Hardwood Log Grading. Northeastern Forest Experiment Station, Upper Darby, PA. 50 p.

2. Date introduced: 1965.

3. Log Grades: The system contains three distinct log grades, which are similar to the grades introduced in (Lockard, 1957) (citation, p. 11). Changes are made to the construction and local use log grades.

Changes to construction grade:

a) For end defects, unsound is now not to exceed one quarter of the scaling diameter. Changes to local grade:

b) Total cull allowed is now listed as maximum scale deduction allowed and is limited to two thirds of the volume.

4. Scaling system: International $1 / 4$ - inch log rule.

5. Lumber grades considered: Grades are based on yield of NHLA No. 1 Common or better.

6. Impact of defects: three unique defects added by the author, including dormant buds, epicormics branches, bark pockets (citation, p. 16-18).

7. Grades based on: Empirical data from 11,000 logs sawed at 28 sawmills.

8. Applicable regions: Northern Central hardwoods.

9. Presence of special rules: The system has the same special rules and instructions as Lockard (1957).

\section{Hardwood Log Grades for Standard Lumber (Vaughan et al., 1966)}

This is the last document which actually modified the USDA FS FPL log grading system and it has received very little attention since publication, even though it marked the end of the evolution of the USDA FS FPL log grading system. However, the defined system operates the exactly in the same manner of all the USDA FS FPL log grading system with only one change (Appendix E).

1. Literature Citation: Vaughan, C.L., A.C. Wollin, K.A. McDonald, and E.H. Bulgrin. 1966. Hardwood log grades for standard lumber. U.S. Forest Service Research Paper FPL 63. 54pp.

2. Date when first introduced: 1966. 
3. Log Grades: The system contains three distinct log grades same as 1965 except for one change, total scaling deduction for log grade 1 is now 30\% see (Appendix E: Table 1: Log Grades).

4. Scaling system: Doyle, Scribner, and International $1 \frac{1}{4}$ inch log rule.

5. Lumber grades considered - Grades are based on yield of NHLA No. 1 Common or better lumber.

6. Impact of defects: Same as 1965 (citation, p. 6-8).

7. Grades based on: Empirical data from 11,000 logs sawed at 28 sawmills.

8. Applicable regions: Northern, Central, and Southern Hardwoods.

9. Presence of special rules: The system has four special rules which are the same as (Anonymous, 1965) and two instructions one of which is new (Appendix E: Table 1: Log Grades). The new instruction at the bottom of the page is a reference to a table which graphically displays the clear cutting requirements.

\section{Other Log Grading Systems During the USDA FS FPL Timeframe 1941-1965.}

This era is focused on other log grading systems developed during the USDAFS time frame. These systems use both theoretical and empirical data to define log grades. The systems will be evaluated using the nine criteria introduced above.

\section{Empirical Log Rules According to Species Groups and Lumber Grades (Schumacher 1941)}

Schumacher defines an equation-based log grading system that contains three distinct log grades and is based on empirical data collected in Kentucky. The log rule used to determine volume is one the author has created named the Empirical log rule.

1. Literature Citation:

Schumacher, F.X., and H.E. Young. 1941. Empirical log rules according to species groups and lumber grades. Journal of Forestry 41(7):511-518.

2. Date when first introduced: 1941.

3. Log Grades: The system contains three distinct log grades that are differentiated by calculated lumber yield (citation, p. 516).

4. Scaling system: Defined as empirical log rule (citation, p. 511) 
5. Lumber grades considered: Grades are based on yield of NHLA first \& seconds, and No. $1 \& 2$ Common Lumber.

6. Impact of defects: Defects are not clear or well developed at this point.

7. Grades based on: Empirical data from individual log studies.

8. Applicable regions: Kentucky.

9. Presence of special rules: None specified.

\section{Grade Yields and Overrun from Indiana Hardwood Sawlogs (Herrick 1946)}

Herrick details a log grading system that uses the percentage of clear faces on three log faces and small end diameter inside the bark to differentiate grades. The system is based on lumber yields of NHLA grades FAS, No. 1, 2, and 3 common lumber. The log rules used to determine volume are Doyle, Scribner Decimal C, and International 1/4-inch.

1. Literature Citation:

Herrick, A. M. 1946. Grade yields and overrun from Indiana hardwood sawlogs. Purdue University Agricultural Experiment Station, Agr. Exp. Sta. Bul. 516. 60pp.

2. Date when first introduced: 1946.

3. Log Grades: The system contains four distinct log grades that are differentiated by percentage of clear faces on three faces and small end diameter inside bark (citation, $p$. 7).

4. Scaling system: Doyle, Scribner Decimal C, and International $1 / 4 \log$ rules.

5. Lumber grades considered: Grades are based on yield of NHLA FAS, No. 1, 2, 3 Common lumber.

6. Impact of defects: None specified.

7. Grades based on: Empirical data from 862 logs sawn at 9 sawmills.

8. Applicable regions: Indiana, where data was collected.

9. Presence of special rules: None specified.

\section{A Simple Method for Grading Hardwood Logs and Determining Log Values for New Hampshire (Wallace 1948)}

In 1948, Wallace detailed a log grading system based on empirical data, where the log grades are differentiated by small end diameter inside bark and number of clear faces. The 
system divided the logs into four grading faces which were then evaluated independently of each other, focusing on the presence or lack of defects.

1. Literature Citation:

Wallace, O.P. 1948. A simple method for grading hardwood logs and determining $\log$ values for New Hampshire. J. Forestry 46:377-379

2. Date when first introduced: 1948.

3. Log Grades: The system contains four distinct log grades that are differentiated by diameter and number of clear faces (citation, p. 378).

4. Scaling system: International $1 / 4 \log$ rule.

5. Lumber grades considered: Grades are based on yield of NHLA first \& seconds, and No. 1 Common and Selects lumber.

6. Impact of defects: Defects are not clear or well developed at this point.

7. Grades based on: Empirical data from individual log studies.

8. Applicable regions: New Hampshire.

9. Presence of special rules: None specified.

\section{How to Grade Hardwood Sawlogs (Herrick 1949)}

In this publication, Herrick updated the log grading system he developed in 1946 that differentiated log grades by the percentage of clear faces on the poorest three grading faces and small end diameter inside the bark. Herricks (1946) system never specified which three faces were graded. The system was based on lumber yields of NHLA FAS, No. 1, 2, and 3 Common lumber. The impacts of defects were determined by the location of knots. To determine volume, the system used the Doyle log rule.

1. Literature Citation:

Herrick, A.M. 1949. How to grade hardwood sawlogs. Purdue University Agricultural Extension Service, Agr. Ext. Bull. 346. 8pp.

2. Date when first introduced: 1949.

3. Log Grades: The system contains four distinct log grades differentiated by the percentage of clear faces on the poorest three grading faces and small end diameter inside the bark. This is the same as 1946 except now in log grade 2, the three visible faces (or best faces) 
must be at least $50 \%$ clear in two cuttings, neither of which can be less than 3 feet long (citation, p.3).

4. Scaling system: Doyle log rule.

5. Lumber grades considered: Grades are based on yield of FAS, and No. 1, 2, and 3 Common lumber.

6. Impact of defects: Knot location determines reduction in grade (citation, p.4).

7. Grades based on: Empirical data.

8. Applicable regions: Indiana.

9. Presence of special rules: None specified.

\section{Log Grade Classification Based on Standard Lumber Recovery for Inferior Upland}

Hardwoods in East Texas (Kramer, 1952)

Kramer's log grading system was developed for the purchase of low-quality hardwood in East Texas. The system differentiated log grades based on percentage of clear surface and small end inside bark diameter and was based on empirical data collected from 1,109 hardwood logs inventoried and sawn to determine grade separations. The data suggested the log grades should be developed around the yield of No. 1, 2, and 3 Common lumber.

1. Literature Citation:

Kramer, P. R. 1952. Log Grade Classification Based on Standard Lumber Recovery for Inferior Upland Hardwoods in East Texas. Texas Forest Service, Forest Products

Department, Lufkin, TX. Technical Report No. 4. 34pp.

2. Date when first introduced: 1952.

3. Log Grades: The system contains three distinct log grades differentiated by percentage of clear surface and small end inside bark diameter on 3 of the best faces (citation, p. 2627).

4. Scaling system: International $1 / 4 \log$ rule.

5. Lumber grades considered: Grades are based on yield of NHLA No. 1, 2, 3A, and 3B Common lumber.

6. Impact of defects: None specified.

7. Grades based on: Empirical data from 1109 logs.

8. Applicable regions: East Texas.

9. Presence of special rules: None specified. 


\section{A Simple Method for Grading Hardwood Logs (Wallace, 1955)}

Wallace detailed a log grading system based on empirical data where the log grades are differentiated based on small end diameter inside bark and the number of clear faces. This was generally the same system that was produced by Wallace in 1948, except for three variations listed below.

1. Literature Citation:

Wallace, O.P. 1955. A simple method for grading hardwood logs. University of New Hampshire, Agricultural Experiment Station, Durham New Hampshire.Station Technical Bulletin 94. 7pp.

2. Date when first introduced: 1955

3. Log Grades: The system contains four distinct log grades differentiated by small end diameter inside bark and the number of clear faces and same as Wallace (1948) except for the following three (3) changes (citation, p. 2).

a) The addition of two diameter classes for grade two logs: 10 inches -14 inches and over 15 inches.

b) The 15-inch and over group with two clear faces was moved up to grade 3 from grade 4.

c) The 15-inch and over group with one clear face was dropped to grade 3 .

4. Scaling system: International $1 / 4$ inch $\log$ rule.

5. Lumber grades considered: Grades are based on yield of FAS, No. 1, 2, and 3 Common lumber.

6. Impact of defects: A defect will result in disqualification of a grading face as being clear.

7. Grades based on: Empirical data from 1000 log diagrams from the USDAFS log grading data base.

8. Applicable regions: Northern Hardwoods.

9. Presence of special rules: None specified.

\section{Evaluating Quality of Black Walnut Sawlogs (King, 1958)}

King (1958) developed a system around the presence or absence of clear cuttings. Grades are differentiated by the small end diameter inside bark (DIB) and the number and length of clear 
cuttings. The system describes eleven defects that impact grade and uses International $1 / 4$-inch and Doyle log rule to determine volume.

1. Literature Citation:

King, W. W. 1958. Evaluating Quality of Black Walnut Sawlogs. Forest Products Journal, September: 243-248.

2. Date when first introduced: 1958.

3. Log Grades: The system defines three distinct log grades differentiated by the small end diameter inside bark and the number and length of clear cuttings (citation, p. 244).

4. Scaling system: International $1 / 4$ inch or Doyle log rule.

5. Lumber grades considered: FAS, No. 1, 2, and 3 Common lumber

6. Impact of defects: Eleven unique defects noted by the author, including fire scar, seams, frost cracks, double heart, ring shake, heavy dote, decay, bird peck, wormholes, sweep, and crook (citation, p. 247).

7. Grades based on: Empirical data from 576 logs sawn at one sawmill.

8. Applicable regions: Kentucky.

9. Presence of special rules: The system has seven special rules encompassing diameter exceptions and cull deductions (citation, p. 224)

\section{Ohio Standard Saw Log Grades (Ohio Forestry Association 1965)}

The Ohio Forestry Association detailed a log grading system in their 1965 publication that differentiates log grades based on diameter inside bark on the small end and percentage of

clear cuttings in each face. The system describes thirty-eight defects that could impact grade and uses the Doyle log rule to determine volume.

1. Literature Citation:

Ohio Forestry Association. 1965. Ohio standard saw log grades. Ohio Forestry Association, Inc., Columbus, OH. 8pp.

2. Date when first introduced: 1965 .

3. Log Grades: The system contains four distinct log grades differentiated by diameter inside bark and percentage of clear cuttings in each face (citation, p. 4-5).

4. Scaling system: Doyle log rule.

5. Lumber grades considered: None specified. 
6. Impact of defects: Thirty-eight unique defects noted by the author (citation, p. 7).

7. Grades based on: Probably theoretical, no evidence exists that the grades were determined from empirical data.

8. Applicable regions: Ohio

9. Presence of special rules: The system has two distinct rules encompassing special logs and cull logs (citation, p. 4-5).

Since the late 1960's no further development has surfaced that has improved or advanced the standardization of these hardwood log grading systems. The most recently updated system was the USDA FS FPL log grading system by Vaughan, et al. (1966). These systems have been generally ignored by primary wood product producers for raw material purchases. Instead the industry has produced their own proprietary log grading and scaling systems. Subsequently, log grades vary drastically on a mill-to-mill basis because of differences in these proprietary systems.

\section{$\underline{\text { Methods }}$}

Primary wood product producers in the Appalachian region were surveyed to determine how hardwood sawlogs are purchased and to identify grading and scaling measurement protocols that could be used in the development of a national/regional hardwood log grading and scaling system. Using the identified protocols, in tandem with empirical lumber grade yields from individual $\log$, a system could be developed that would produce consistent and fair raw material (log) pricing for the forest products industry.

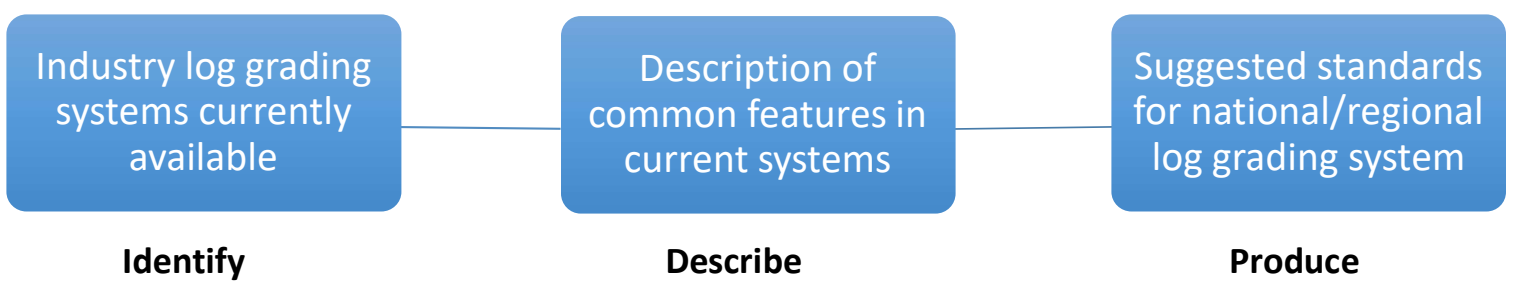

Figure 1. Flowchart of this research effort to identify current log grading systems and to provide standards for a regional grading system. 
To meet the noted study objectives, this research effort identifies currently available log grading systems, common features and characteristics among these systems, and finally suggests a set of defined standards for a log grading system (Figure 1).

A survey instrument was developed to identify and assess current log grading systems being used in the Appalachian region (Appendix A). Company information was provided by two different sources. The first source was the Appalachian Hardwood Manufacturers Inc. (AHMI). The mission of AHMI is to promote the benefits of logs, lumber, and products sourced from the Appalachian region. AHMI is committed to sustaining the forests of the Appalachian region with modern forest management practices and efforts have helped increase the region to more than 65 million forested acres with a growth to removal ratio of 2.4 to 1 . AHMI member data included primary wood product producers from nine (9) different states, including Ohio, New York, West Virginia, Pennsylvania, Tennessee, Virginia, North Carolina, Maryland, and Kentucky.

The second source was from state forestry agencies that provided contact information for non-AHMI member companies, with lists of these companies obtained from individual state forestry agencies and associations in the same nine states. These lists were carefully parsed and combined to ensure no duplicates were present. The combined nine-state list was finally adjusted to include only those wood-products producers that actively graded hardwood sawlogs. Thus, only primary wood product producers and log buyers were included in the study.

Once the lists were finalized, a total of 1,085 records of wood product producers from both AHMI and non-AHMI member companies were available. The AHMI member list contained 45 records of hardwood primary wood product producers and the non-AHMI member companies list contained 1,040 records. These lists were formatted to have the same attributes; Company Name, Address, City, State, Zip Code, and County. The recommended level of response for this study was 269 responses, determined using a table developed by Krejcie and Morgan (1970). This table projects the number of responses needed to make the results as accurate as possible. However, several researchers who work with surveys to the industry suggested that a ten percent response rate was a more appropriate target (Hassler, pers. comm.; Boone, pers. comm.).

The survey instrument was developed to focus on how primary wood product producers' grade and scale hardwood sawlogs at the mill. The instrument was sent to 45 AHMI member companies to ensure that the questions were clear and that the obtained information was valid. 
This ensured that the instrument obtained the necessary data related to log grading and scaling in the Appalachian region. The responses from the non-member companies were then combined with the AHMI responses to prepare the data for statistical analysis.

The survey was developed in three sections. The first section pertained to log rules, production and acquisition. The second section focused on the scaling and grading of logs, and the third section focused on current grading specifications, production costs, and support for changing grading systems.

The survey questions used to investigate the way respondents handle the scaling of hardwood logs contained eleven questions with both open ended and dichotomous responses that ranged from the types of log rules used, to how end defects of logs are handled.

The section focused on the scaling and grading of logs included three questions with both open ended and dichotomous responses related to grading hardwood logs. Two questions investigated procedures used when evaluating the quality of logs, while the last question assessed the attitude of primary wood product producers towards a standardized hardwood log grading system.

The section focused on other factors influencing production included questions ranging from how raw material is purchased to the real cost of operation. This section of the survey consisted of eleven questions with both open ended and dichotomous responses.

Data Collection Procedures

The survey instrument was sent to primary producers starting in June 2018 with an expected return date of August 15, 2018. Because there were no personal identifiers on the original survey, follow-up surveys were not sent due to proprietary nature of the information.

Survey responses were entered electronically as received. The data was then grouped around annual production level, so that natural breaks, as defined by the study team, resulted in three separate groupings. If the groups were not relatively even, it would tend to skew the data and results by potentially overwhelming one or more groupings.

Frequency distributions were developed for each survey response and used to categorize data. This ensured, within the natural breaks, that no more than $25 \%$ of the cells had cell counts less than five.

Due to the nominal structure of the data, where the data is categorized by frequency counts, the Chi-Square Test of Independence, in the form of an $\mathrm{r} x \mathrm{c}$ contingency table was used 
for all statistical analyses. The data collected for this study were reported by annual mill production (in board feet) and either dichotomous or open-ended responses. As such, the "r" rows and "c" columns of each table represent the production size class level and the variable of interest. Once all variables are classified, the cell count represents the frequency counts or the observed value that belongs to each cell.

The assumptions for this test are detailed by Conover (1980):

1. The total sample, $\mathrm{N}$, of observations is a random sample (i.e., "Each observation has the same probability as every other observation of being classified in row $\mathrm{i}$ and column $\mathrm{j}$, independently of other observations".)

2. Each response can be classified into only one protocol by production level.

3. A nominal scale of measurement is all that is required.

The hypothesis under consideration here is that rows and columns (production level and response, respectively) represent two independent classification schemes.

The test statistic for this procedure is defined by Conover (1980) as follows:

$$
T=\sum_{i=1}^{r} \sum_{j=1}^{c} \frac{\left(O_{i j}-E_{i j}\right)^{2}}{E_{i j}}
$$

Where,

$\mathrm{T}=$ the test statistic, where rejection of the null hypothesis takes place when $\mathrm{T}$ exceeds the 1- quantile of a chi-square random variable with (r-1) (c-1) degrees of freedom, $\mathrm{O}_{\mathrm{ij}}=$ the number of observations (responses) that fall into the $\mathrm{i}^{\text {th }}$ row and $\mathrm{j}^{\text {th }}$ column of the $\mathrm{r}$ x c contingency table, $E_{i j}=$ the expected number of the observations in the $i^{\text {th }}$ row and $j^{\text {th }}$ column of the $\mathrm{r} x \mathrm{c}$ contingency table and is calculated as $\left(\mathrm{R}_{\mathrm{i}} \mathrm{C}_{\mathrm{j}}\right) / \mathrm{N}$, where $\mathrm{R}_{\mathrm{i}}$ is the total number of observations in row $\mathrm{i}, \mathrm{C}_{\mathrm{j}}$ is the total number of the observation in column $\mathrm{j}$, and $\mathrm{N}$ is the total number of observations in the sample.

For example, when primary wood product producers are asked if they "grade logs as they lay", the responses were either yes or no, by size of production. When using a statistical analysis software package to conduct the test the program calculates an expected and observed value for each yes and no category by production size (R Core Team, 2019). With this calculation the program also determines the chi-square value, T, equal to the sum of the cell 
contributions and the $\mathrm{P}$ value, which indicates if the data set has significant differences or not. The $\mathrm{P}$ value was set to $\alpha \leq 0.05$ in this study and when reported in text format for significance is represented by $\mathrm{T}$ and $\mathrm{P}$ ( $\mathrm{R}$ Core Team, 2019). Once a statistically significant test is produced the variables can be examined to determine the origin of the significance. The observed categorical variable that contributes significantly to the overall $\mathrm{T}$ value can be determined by the cell contributions of the expected values. Normally, when a chi-square test of independence determines a statistically significant result, three or more of expected variable contributions are greater than one.

Finally, with each survey, participants were asked to provide specification sheets that described their current log grading and pricing matrix, by log grade and species. The specification sheets provided were analyzed by focusing on the highest and second highest log grades, excluding veneer log grades. In some cases, other characteristics were included when assigning a log grade, such as butt log versus upper log, log length (assign a lower grade to an 8foot $\log$, for instance), among others. The individual mill log grades were used to populate a matrix based on the number of clear faces and scaling diameter. The matrix was defined with 5 (five) levels of clear faces $(0,1,2,3$, and 4 clear faces) and 11 (eleven) scaling diameter classes ( 8 inches to $18+$ inches in 1 inch increments). For example, if the highest log grade specified by a mill included 4 clear faces and a scaling diameter of $17+$ inches, then two cells of the matrix would each receive one frequency count (4 clear faces/17 inches scaling diameter and 4 clear faces/18+ inches scaling diameter). In this way, the variability in how the two highest log grades are categorized by responding mills is illustrated. 


\section{$\underline{\text { Results and Discussion }}$}

A total of the 1,085 surveys were mailed to primary wood product producers. Seven mills reported no longer being in business and six reported not being primary wood product producers. A total of 111 surveys were returned because of invalid addresses. From this information, we estimated that the survey reached 961 primary wood product producers. The total number of responses was 135 , with only 110 surveys considered useable. A total of 21 surveys were from members of AHMI and 89 surveys came from the non-AHMI member population. The two data sets were not tested against one another, but rather tested as one population.

The study response rate was $14.0 \%$ (135/961) and the total usable valid population was 11.4\% (110/961). Pennsylvania had the greatest number of returned surveys (19) with a response rate of 11\%, followed by Kentucky and West Virginia (13) responses. Virginia had the highest level of response based on total sent at 13\% (Table 1).

Table 1. Geographic distribution of useable survey responses to the survey on grading and scaling hardwood sawlogs in the Appalachian region.

\begin{tabular}{lcccc}
\hline State & $\begin{array}{c}\text { Respondent } \\
\text { Frequency }\end{array}$ & $\begin{array}{c}\text { Number } \\
\text { Sent }\end{array}$ & $\begin{array}{c}\text { Number } \\
\text { Delivered }\end{array}$ & $\begin{array}{c}\text { Response } \\
\text { Rate }\end{array}$ \\
\hline KY & 13 & 117 & 103 & $11 \%$ \\
MD & 3 & 25 & 25 & $12 \%$ \\
NC & 12 & 111 & 92 & $11 \%$ \\
NY & 5 & 55 & 53 & $9 \%$ \\
OH & 8 & 129 & 124 & $6 \%$ \\
PA & 19 & 172 & 169 & $11 \%$ \\
TN & 11 & 257 & 221 & $4 \%$ \\
VA & 14 & 106 & 79 & $13 \%$ \\
WV & 13 & 113 & 108 & $12 \%$ \\
No State Provided & 12 & 0 & 0 & $1.2 \%$ \\
Closures and Others & -13 & 0 & -13 & $-1.3 \%$ \\
Total & $\mathbf{1 1 0}$ & $\mathbf{1 0 8 5}$ & $\mathbf{9 6 1}$ & $\mathbf{1 1 . 4 \%}$ \\
\hline
\end{tabular}

\section{$\underline{\text { Respondent Demographics }}$}

All mills provided annual production levels in their survey response. Respondents production ranged from 0.04 to $150 \mathrm{mmbf}$ with a mean of $9.9 \mathrm{mmbf}$ of production. Annual production information was classified into three groups based on natural breaks (Table 2), which 
resulted in a very uniform distribution of responses over the 3 production levels. The three production levels are defined as follow:

Level 1: $>0.0$ and $\leq 2.5$ million board feet

Level 2: $>2.5$ and $\leq 8.0$ million board feet

Level 3: > 8.0 million board feet

These production groupings were used for all subsequent analyses.

Table 2. Annual production levels (in million board feet) for all useable survey respondents.

\begin{tabular}{lcr}
\hline Production level & $\begin{array}{c}\text { Number of } \\
\text { Producers }\end{array}$ & $\begin{array}{r}\text { Percent of } \\
\text { Producers }\end{array}$ \\
\hline $1(>0.0$ to $\leq 2.5 \mathrm{mmbf})$ & 35 & $31.8 \%$ \\
$2(>2.5$ to $\leq 8.0 \mathrm{mmbf})$ & 37 & $33.7 \%$ \\
$3(>8.0 \mathrm{mmbf})$ & 38 & $34.5 \%$ \\
Total & $\mathbf{1 1 0}$ & $\mathbf{1 0 0 . 0 \%}$ \\
\hline
\end{tabular}

For the remainder of this discussion, the term total number of responses will refer to the number of useable responses to the survey question under discussion, not the total number of responses to the survey. While 110 responses were deemed useable, certain questions were not answered by some respondents, therefore the analyses were performed on the useable responses for each question. 
Shown in Table 3 is the breakdown of annual production level by state for survey respondents.

Table 3. Number of primary wood product producers in KY, MD, NC, NY, OH, PA, TN, VA, and WV separated by annual production level.

\begin{tabular}{lrrrrrrrrr}
\hline $\begin{array}{l}\text { Production Level } \\
\text { State }\end{array}$ & $\mathbf{n}$ & $\mathbf{1}$ & $\mathbf{n}$ & $\mathbf{2}$ & $\mathbf{3}$ & $\mathbf{n}$ & $\mathbf{\%}$ & \multicolumn{2}{c}{ Total } \\
\hline KY & 6 & $5.44 \%$ & 4 & $3.64 \%$ & 3 & $2.73 \%$ & 13 & $11.82 \%$ \\
MD & 2 & $1.82 \%$ & 0 & $0.00 \%$ & 1 & $0.90 \%$ & 3 & $2.73 \%$ \\
NC & 4 & $3.64 \%$ & 5 & $4.55 \%$ & 3 & $2.73 \%$ & 12 & $10.91 \%$ \\
NY & 1 & $0.90 \%$ & 2 & $1.82 \%$ & 2 & $1.82 \%$ & 5 & $4.55 \%$ \\
OH & 3 & $2.73 \%$ & 3 & $2.73 \%$ & 2 & $1.82 \%$ & 8 & $7.27 \%$ \\
PA & 5 & $4.55 \%$ & 11 & $10.00 \%$ & 3 & $2.73 \%$ & 19 & $17.27 \%$ \\
TN & 5 & $4.55 \%$ & 4 & $3.64 \%$ & 2 & $1.82 \%$ & 11 & $10.00 \%$ \\
VA & 1 & $0.90 \%$ & 4 & $3.64 \%$ & 9 & $8.18 \%$ & 14 & $12.73 \%$ \\
WV & 4 & $3.64 \%$ & 2 & $1.82 \%$ & 7 & $6.36 \%$ & 13 & $11.82 \%$ \\
No State Provided & 4 & $3.64 \%$ & 2 & $1.82 \%$ & 6 & $5.44 \%$ & 12 & $10.90 \%$ \\
Total & $\mathbf{3 5}$ & $\mathbf{3 1 . 8 \%}$ & $\mathbf{3 7}$ & $\mathbf{3 3 . 7 \%}$ & $\mathbf{3 8}$ & $\mathbf{3 4 . 5 \%}$ & $\mathbf{1 1 0}$ & $\mathbf{1 0 0 . 0 \%}$ \\
\hline
\end{tabular}

\section{$\underline{\text { Scaling Protocols }}$}

The scaling of hardwood logs in the industry is arguably just as important as grading, due to the nature of the way prices are assessed in relation to the total board foot volume of a log. Scaling a hardwood log is the action that is used to determine volume of hardwood logs. The two measurements required to determine log volume are diameter and length. Diameter for hardwood logs is determined by measuring the diameter inside the bark at the small end of the $\log$ or (d.i.b.). The total length of a $\log$ is measured in feet. Many specification sheets will differentiate log lengths either with or without trim. Trim is a set requirement in the sale of hardwood logs and is used in the production of lumber to trim lumber to set lengths as defined by the mill. Once these two measurements have been determined the corresponding measurement values are used in an established log rule to determine total log volume.

Three log rules are consistently used by the industry and include Scribner Log Rule developed by J. M. Scribner in 1846, and based around diagrams of logs with different diameters, drawn to scale, showing the number of 1-inch boards, with saw kerf included, that could be sawn from that $\log$.. This $\log$ rule accounts for a $1 / 4$ inch saw kerf and does not take 
taper into account. A general rule of thumb equation for the Scribner log rule is 0.8 (D-1) ${ }^{2}-$ $\mathrm{D} / 2$. This $\log$ rule is intermediate in accuracy due to the changes in volume not being entirely consistent with changes in log diameters. At a later point the log rule was modified and renamed to Scribner Decimal C where the original volumes were rounded off to the nearest ten board feet and the last zero dropped. This was intended to help log scalers and grades when large volume of logs had to be inventoried (Avery, T.E., \& Burkhart H.E., 1983, pp. 46).

Doyle Log Rule was created by Edward Doyle in 1825 and uses an algebraic equation for determining volume.

$$
b d f t=((D-4) / 4)^{2} L
$$

This $\log$ rule has proved to be the favorite of the industry. It accounts for 4 inches of slabbing allowance and 5/16 inches of saw kerf. This has created a log rule that underestimates log volume, with the most severe underestimation occurring for small logs and approaching the actual volume once $\log$ diameter reaches about 24 to 28 inches DIB. At that point the Doyle rule overestimates volume for larger diameter logs (Avery, T.E., \& Burkhart H.E., 1983, pp. 46-48).

The International Log Rule was created in 1906 by Judson Clark and is considered to be the most accurate of the currently used log rules. The International Log Rule is equation based and takes taper into account with a fixed allowance of $1 / 2$ inch per $4 \mathrm{ft}$ of $\log$ length. This $\log$ rule has two different kerf allowance specifications $1 / 8$ inch and $1 / 4$ inch. The $1 / 8$ inch kerf version was developed for use in bandsaw head rig mills and $1 / 4$ inch kerf is for use in circular saw type milling operations (Avery, T.E., \& Burkhart H.E., 1983 pp. 48-49).

The most common log rule used by mills in this study was the Doyle log rule, with 83 of 109 mills reporting its use (Table 4). The second most commonly used log rule was International $1 / 4 \log$ rule with twelve responses, Scribner decimal $C \log$ rule with eleven, and a combination of $\log$ rules with three responses. The Doyle log rule was used consistently over all nine states in the sample, with Ohio and West Virginia using it exclusively. The International $\log$ rule saw the greatest use in Virginia and North Carolina, while the Scribner log rule was used mostly in Pennsylvania and North Carolina. 
Table 4. Number of primary wood product producers in KY, MD, NC, NY, OH, PA, TN, VA, and WV separated by annual production level and log rule used to determine log volume.

\begin{tabular}{|c|c|c|c|c|c|c|c|c|c|c|c|c|c|}
\hline Log Rule & \multicolumn{3}{|c|}{ Doyle } & \multicolumn{3}{|c|}{ Int'l. } & \multicolumn{3}{|c|}{ Scribner } & \multicolumn{3}{|c|}{ Combination } & \multirow[t]{2}{*}{ Total } \\
\hline State Prod Level & 1 & 2 & 3 & 1 & 2 & 3 & 1 & 2 & 3 & 1 & 2 & 3 & \\
\hline KY & 5 & 4 & 3 & 1 & 0 & 0 & 0 & 0 & 3 & 0 & 0 & 0 & 16 \\
\hline MD & 1 & 0 & 1 & 0 & 0 & 0 & 0 & 0 & 0 & 1 & 0 & 0 & 3 \\
\hline $\mathrm{NC}$ & 3 & 2 & 0 & 0 & 2 & 0 & 0 & 1 & 0 & 0 & 0 & 0 & 8 \\
\hline NY & 0 & 2 & 1 & 1 & 0 & 0 & 0 & 0 & 0 & 0 & 0 & 1 & 5 \\
\hline $\mathrm{OH}$ & 3 & 3 & 2 & 0 & 0 & 0 & 0 & 0 & 0 & 0 & 0 & 0 & 8 \\
\hline PA & 2 & 6 & 2 & 0 & 1 & 0 & 3 & 3 & 1 & 0 & 1 & 0 & 19 \\
\hline $\mathrm{TN}$ & 5 & 3 & 2 & 0 & 1 & 0 & 0 & 0 & 0 & 0 & 0 & 0 & 11 \\
\hline VA & 0 & 4 & 6 & 1 & 0 & 3 & 0 & 0 & 0 & 0 & 0 & 0 & 14 \\
\hline WV & 4 & 2 & 7 & 0 & 0 & 0 & 0 & 0 & 0 & 0 & 0 & 0 & 13 \\
\hline No State Provided & 4 & 1 & 5 & 0 & 1 & 1 & 0 & 0 & 0 & 0 & 0 & 0 & 12 \\
\hline Total & 27 & 27 & 29 & 3 & 5 & 4 & 3 & 4 & 4 & 1 & 1 & 1 & 109 \\
\hline
\end{tabular}

Mills were asked whether they buy logs of even lengths only or if they also buy odd length logs. A total of 62 (57.9\%) mills purchased only even length logs (Table 5). This creates a possible situation where a logger produces a 9-foot log, sells it as an 8-foot log to the mill, and the mill then produces and sells 9-foot boards.

The chi-square test of independence was performed to evaluate the relationship between level of production and if the mill purchases even length $\operatorname{logs}(8,10,12,14$, and 16 feet) or both odd and even lengths $(8,9,10,11,12,13,14,15$, and 16). No statistical relationship was noted between purchases of just even length logs and both odd and even length logs, by mill production $(\mathrm{T}=0.26, \mathrm{P}<0.887)$.

Mills were asked how they determine scaling diameter of sawlogs. Four options were detailed in the survey: Average - The largest and smallest measurement taken through the center of the heart added together and divided by two; Short-way only (SWO) - the shortest measurement of diameter crossing through the heart of the log; Short-way then 90 degrees to that- (SW+90) - the shortest measurement of diameter crossing through the heart of the log and then 90 degrees to that and adding those two measurements together and dividing by two; and Other including purchasing logs by weight and measuring just the small end of the log inside bark (with no further explanation). 
Table 5. Do mills purchase even length logs or both even and odd length logs, by annual production level in the Appalachian region?

\begin{tabular}{rlrrr}
\hline Production Level & Just even lengths & Odd and even length & Total \\
\hline \multirow{2}{*}{1} & Observed & 18 & 15 & 33 \\
& Expected & 19.12 & 13.88 & 36 \\
2 & Observed & 21 & 15 & \\
& Expected & 20.86 & 15.14 & 38 \\
3 & Observed & 23 & 15 & \\
& Expected & 22.02 & 15.98 & $\mathbf{1 0 7}$ \\
\hline$* a \leq 0.05 \cdot \mathrm{P}<0.887$ & $\mathbf{6 2}$ & $\mathbf{4 5}$ &
\end{tabular}

Of the mills sampled, 45 or $42.9 \%$ measured diameter inside bark at the small end by averaging the smallest and largest measurement. This was followed by measuring short way then 90 degrees to that and average with 33 or $31.4 \%$ of responses. The least reported was other with 3 or $2.9 \%$ responses (Table 6 ). While averaging the smallest and largest measurement generates an average diameter, it tends to overestimate diameter. Using the shortest measurement though the heart and then taking a second diameter reading 90 degrees from that measurement should be much more consistent when trying to estimate the usable amount of wood for lumber production.

The chi-square test of independence showed a statistical relationship existed between the measurement of scaling diameter and size of production $(\mathrm{T}=15.94, \mathrm{P}<0.014)$. More size 1 mills than expected responded "Short-way only" (SWO) and for mill size 3, more than expected responded "Other". Furthermore, fewer than expected mill size 3 responded "Short-way only" (SWO).

Table 6. How do mills determine scaling diameter, by annual production level in the Appalachian region?

\begin{tabular}{lcccccc}
\hline $\begin{array}{l}\text { Production Level: } \\
\text { Response }\end{array}$ & \multicolumn{2}{c}{$\mathbf{1}$} & \multicolumn{2}{c}{ 2 } & \multicolumn{2}{c}{$\mathbf{3}$} \\
\hline Observed & Expected & Observed & Expected & Observed & Expected \\
SWO & 11 & 14.57 & 19 & 15.43 & 15 & 15.00 \\
SW\&90 & $14 *$ & 7.77 & 6 & 8.23 & $4 *$ & 8.00 \\
Other & 9 & 10.69 & 11 & 11.31 & 13 & 11.00 \\
Total & 0 & 0.97 & 0 & 1.03 & $3 *$ & 1.00 \\
* $a \leq 0.05^{*}{ }^{*}$ Statistically significant at $0.05 \cdot \mathrm{P}<0.014$ & & & & $\mathbf{3 5}$ & $\mathbf{1 0 5}$ \\
\hline
\end{tabular}


Mills were asked how they handle fractional inches when measuring the scaling diameter of sawlogs. This is a protocol that falls across a broad spectrum of techniques.

a. If the fractional portion equals 0.5 inches, alternate rounding up and down - This means the log grader is rounding up and down every other log where the diameter falls on 0.5 inches.

b. If the fractional portion is $\leq 0.5$ inches round down, round up if $\geq 0.75$ inches This rule of thumb measurement protocol implies the log grader will not round the diameter to the next full inch unless the fraction of the inch is $\geq 0.75$ inches or larger.

c. If the fractional portion is $\geq 0.5$ inches the log diameter will be rounded to the next full inch.

d. Round down the fractional portion in all instances.

e. Round up or down depending on the quality - On good logs, round up and on bad logs, round down.

f. Round up if $\geq 0.75$ inches- if the diameter is 0.75 inches or greater, the diameter is rounded to the next full inch.

g. $\leqq 0.5$ inches round down - Any fractional proportion of diameter equal to or less than 0.5 inches will be rounded down.

h. Others - these responses generally implied that when scaling logs, the diameter measurements were not rounded.

About 34 percent of the surveyed mills handled fractional diameter measurements by rounding up if the fraction is $\geq 0.5$ inches ( 33 responses). Another 23 companies $(23.7 \%)$ reported that if the measurement equaled 0.5 inches, alternate rounding up and down. The statistical mode for this test falls on rounding up $\geq 0.5$ inches. This is a fair assessment and should be used by the industry. The other techniques used currently for purchasing logs either strongly benefit the mill or logger in an unfair way.

The chi-square test of independence showed a statistical relationship existed between the fractional diameter measurements and size of mill production $(\mathrm{T}=25.02, \mathrm{P}<0.034)$. In this case, more size 1 mills than expected responded that they round using the following rule (b) if $\leq 0.5$ inches, round down, round up if $\geq 0.75$ inches". Furthermore, fewer than expected mill size 
1 responded that they used the following rule (a) " $=0.5$ inches, alternate rounding up and down" while more than expected mill size 3 reported its use. For size 2 mills, fewer than expected responded that they used the following rule (b) " $\leq 0.5$ inches, round down, round up if $\geq 0.75$ inches", while more than expected reported letter designation (g) " $\leq 0.5$ inches round down" (Table 7).

Table 7. How do mills handle fractional proportions of diameter, by annual production level in the Appalachian region?

\begin{tabular}{crrrrrr}
\hline $\begin{array}{c}\text { Prod Level } \\
\text { Response }\end{array}$ & \multicolumn{1}{c}{$\mathbf{1}$} & \multicolumn{2}{c}{$\mathbf{2}$} & \multicolumn{2}{c}{$\mathbf{3}$} \\
Observed & Expected & \multicolumn{1}{c}{ Observed } & Expected & Observed & Expected \\
\hline A & $2^{*}$ & 7.11 & 8 & 8.06 & $13^{*}$ & 7.82 \\
B & $6^{*}$ & 2.16 & $0^{*}$ & 2.45 & 1 & 2.38 \\
C & 13 & 10.21 & 11 & 11.57 & 9 & 11.23 \\
D & 2 & 2.78 & 4 & 3.15 & 3 & 3.06 \\
E & 3 & 1.86 & 2 & 2.10 & 1 & 2.04 \\
F & 0 & 0.93 & 2 & 1.05 & 1 & 1.02 \\
G & 1 & 2.47 & $5 *$ & 2.80 & 2 & 2.72 \\
H & 3 & 2.47 & 2 & 2.80 & 3 & 2.72 \\
Total & $\mathbf{3 0}$ & & $\mathbf{3 4}$ & & $\mathbf{3 3}$ & $\mathbf{9 7}$ \\
\hline
\end{tabular}

Response Key: $* a \leq 0.05^{+}$Statistically significant at $0.05 \cdot \mathrm{P}<0.034$

$\mathrm{a}=0.5$ inches, alternate rounding up and down

$\mathrm{b} \leq 0.5$ inches, round down, round up if $\geq 0.75$ inches

${ }^{\mathrm{c}}$ Round up if $\geq 0.5$ inches

dRound down

eRound up or down depending on the quality

${ }^{f}$ Round up if $\geq 0.75$ inches

$\mathrm{g} \leq 0.5$ inches round down

hOther

Double hearts are prevalent in many hardwood sawing operations and have a negative effect on the value and quality of lumber. Double heart is created when the bole of a tree diverges, forming two forks. 

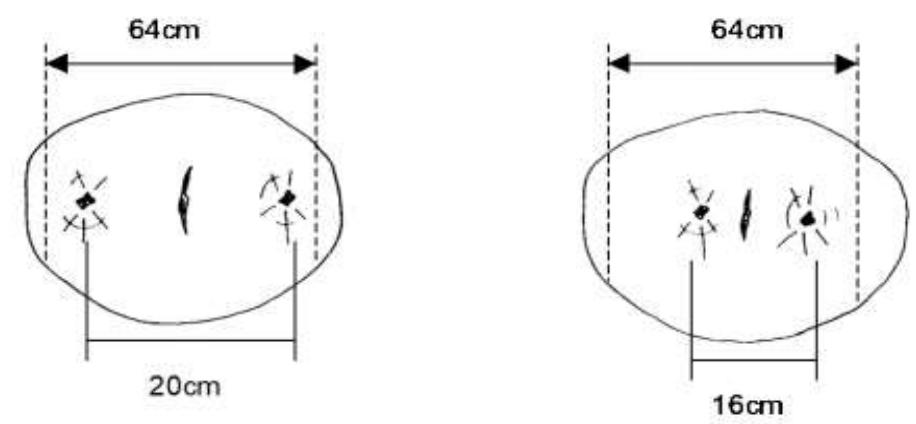

Figure 2. Double hearts in hardwood logs (Anonymous, p. 23, 2001)

Mills were asked about how they handle any scale deductions for logs with double hearts.

Of the mills sampled, 27 (27.8\%) indicated they use a length deduction when dealing with double heart. An equal number of mills responded that they typically measure the diameter of the $\log$ the "short way". Only four (4.1\%) mills used diameter deduction. Due to the generally egg-shaped nature of double heart, making a length deduction is probably the most logical representation of log volume. No statistical relationship existed between the measurement of double heart and size of mill production $(\mathrm{T}=9.72, \mathrm{P}<0.881)$ (Table 8$)$.

Table 8. How primary wood product producers handle the measurement of double hearts by annual production level in the Appalachian region.

\begin{tabular}{|c|c|c|c|c|c|c|}
\hline $\begin{array}{l}\text { Prod Level } \\
\text { Response }\end{array}$ & $\begin{array}{l}1 \\
\text { Observed }\end{array}$ & Expected & $\begin{array}{l}2 \\
\text { Observed }\end{array}$ & Expected & $\begin{array}{l}3 \\
\text { Observed } \\
\end{array}$ & Expected \\
\hline 1 & 2 & 2.61 & 3 & 2.69 & 3 & 2.69 \\
\hline 2 & 2 & 1.96 & 2 & 2.02 & 2 & 2.02 \\
\hline 3 & 2 & 1.31 & 2 & 1.35 & 0 & 1.35 \\
\hline 4 & 1 & 2.61 & 4 & 2.69 & 2 & 2.69 \\
\hline 5 & 10 & 8.82 & 7 & 9.09 & 10 & 9.09 \\
\hline 6 & 1 & 1.63 & 3 & 1.68 & 1 & 1.68 \\
\hline 7 & 1 & 1.63 & 3 & 1.68 & 1 & 1.68 \\
\hline 8 & 11 & 8.82 & 7 & 9.09 & 9 & 9.09 \\
\hline 9 & 2 & 2.61 & 2 & 2.69 & 4 & 2.69 \\
\hline Total & 32 & & 33 & & 32 & 97 \\
\hline
\end{tabular}

Response Key: *a $\leq 0.05 \cdot \mathrm{P}<0.881$

Response Options:

1 Measure diameter across the bark seam of double heart

2 Average of the shortest and longest measurement

3 Diameter deduction

4 Full scale, no deductions

$\begin{array}{ll}5 & \text { Length deduction } \\ 6 & \text { Scale from opposite end } \\ 7 & \text { Scale one heart } \\ 8 & \text { Short way only (SWO) } \\ 9 & \text { Other }\end{array}$

Traditionally, many mills have differentiated between butt logs and upper logs when assigning prices, as did the USDA FS with their log grading system. Of the mills sampled, 55 
(50.4\%) indicated they do not pay differently for butts and upper logs with the same diameter and same number of clear faces (Table 9). Butt logs are also generally more valuable than uppers, due to the amount clear wood that they contain.

The chi-square test of independence showed no statistical relationship between the purchase of logs based on their position within the tree they are bucked from and size of mill production $(\mathrm{T}=0.02, \mathrm{P}<0.991)$.

Table 9. Do primary wood product producers pay differently for butt logs than uppers by annual production level in the Appalachian region?

\begin{tabular}{rrrrr}
\hline Production Level & Response & No & Yes & Total \\
\hline \multirow{2}{*}{1} & Observed & 17 & 17 & 34 \\
& Expected & 17.16 & 16.84 & \\
2 & Observed & 19 & 18 & 37 \\
& Expected & 18.67 & 18.33 & \\
3 & Observed & 19 & 19 & 38 \\
& Expected & 19.17 & 18.83 & \\
& Total & $\mathbf{5 5}$ & $\mathbf{5 4}$ & $\mathbf{1 0 9}$ \\
\hline${ }^{*} a \leq 0.05 \cdot \mathrm{P}<0.991$ & & &
\end{tabular}

In the process of scaling logs for volume, scaling defects present a range of issues in how these defects are handled. Several questions were posed about scaling defects, specifically sweep, holes, and shake. Perhaps the most difficult aspect of log scaling is in dealing with scaling defects and developing a basic understanding of how they are handled. Learning how they are most commonly handled within the industry will, however, help determine the best options for a standardized scaling system.

Sweep is a scaling defect that occurs when significant deflection is present in a log. Sweep is most prevalent in upper logs but can exist in butt logs. This is due, in part, to a tree's tendency to grow toward light in canopy gaps.

Holes are scaling defects that occur due to heart rot that affects the section of the log where the cant is located. Holes are an end defect and can range in severity based on how far the hole extends into the log. From a visual perspective, it is difficult to assess the potential impact of a hole, with its associated decay, on lumber recovery and quality. Dote in hardwood logs is the beginning of heart rot where the wood becomes extremely soft of punky and cannot be used 
in lumber production. These end features can have varying effects on the value of certain logs all related to the severity of the decay.

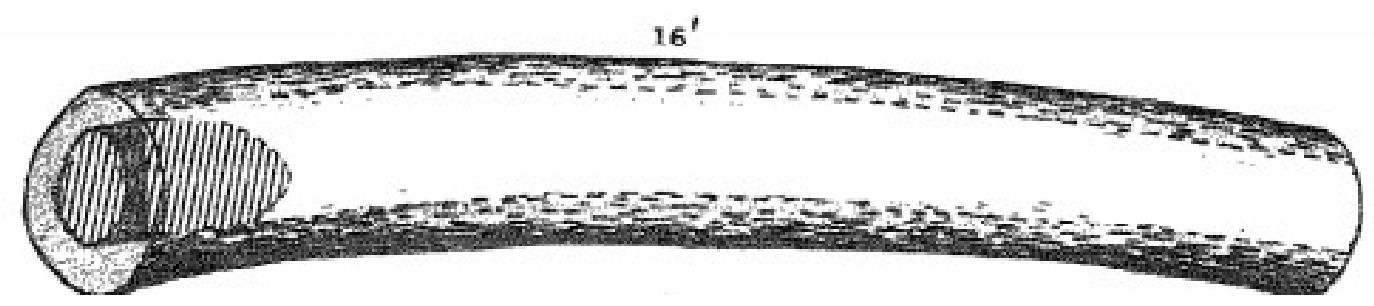

Figure 3. A diagram of sweep and holes in hardwood logs (Rast, E.D., Sonderman, D.L., Gammon, G.L., p. 13, 1973)

Shake occurs as an end defect in hardwood logs, where the growth rings separate from each other. Shake can be caused by a multitude of things, although shake most commonly results from extreme wind events that cause twisting or bending of the bole. This defect causes the lumber in the log to fall apart during the milling process or as it dries following manufacture. Logs with excessive shake typically receive a length deduction due to the unusable nature of the lumber. Figure 4 also provided another example of a hole defect in hardwood logs.

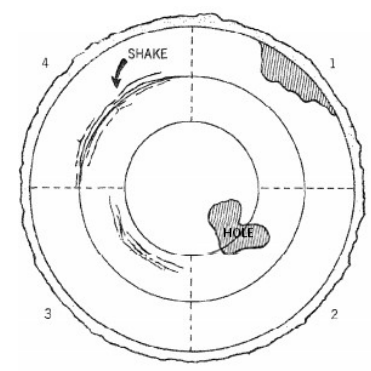

Figure 4. A diagram of shake and holes in hardwood logs (Rast, E.D., et al., p. 19, 1973)

From the survey responses, 33 (36.6\%) of the responding mills indicated that they use a diameter and length deduction when handling sweep, followed by 30 mills (33.3\%) indicating the use of a diameter deduction. Sixteen (17.7\%) respondents indicated they use a length deduction only, and eleven (12.2\%) indicated they did not use any kind of diameter or length deduction (Table 10). Other rule of thumb deductions were made from visual assessments of the loss of board footage caused by the defect. A chi-square test of independence showed no 
statistical relationship between the different deduction methods based on sweep and annual mill production levels $(\mathrm{T}=7.68, \mathrm{P}<0.262)$.

Table 10. How primary wood product producers handle sweep deductions by annual production level in the Appalachian region.

\begin{tabular}{|c|c|c|c|c|c|c|c|}
\hline \multicolumn{2}{|c|}{ Prod Level } & \multirow[t]{2}{*}{ Response } & \multirow{2}{*}{$\begin{array}{c}\text { Neither } \\
2\end{array}$} & \multirow{2}{*}{$\frac{\text { Length }}{6}$} & \multirow{2}{*}{$\begin{array}{c}\text { Diameter } \\
12\end{array}$} & \multirow{2}{*}{$\begin{array}{r}\text { Both } \\
8\end{array}$} & \multirow{2}{*}{$\begin{array}{r}\text { Total } \\
28\end{array}$} \\
\hline 1 & Observed & & & & & & \\
\hline & Expected & & 3.42 & 4.98 & 9.33 & 10.27 & \\
\hline \multirow[t]{2}{*}{2} & Observed & & 2 & 4 & 9 & 15 & 30 \\
\hline & Expected & & 3.67 & 5.33 & 10.00 & 11.00 & \\
\hline \multirow[t]{3}{*}{3} & Observed & & 7 & 6 & 9 & 10 & 32 \\
\hline & Expected & & 3.91 & 5.69 & 10.67 & 11.73 & \\
\hline & Total & & 11 & 16 & 30 & 33 & 90 \\
\hline
\end{tabular}

Responses to how responding mills account for holes or interior defects during the scaling process suggested that $34(36.9 \%)$ responding mills use both diameter and length when making deductions for holes, while 25 (27.2\%) of respondents use only a length deduction. Twenty-three (25\%) were using diameter only and ten (10.9\%) indicated they did not use any kind of diameter or length deduction (Table 11). Other rule of thumb deductions were made from visual assessments of the loss of board footage caused by the defect. The chi-square test of independence showed no statistical relationship between the deductions based on holes and annual mill production $(\mathrm{T}=7.6, \mathrm{P}<0.269)$.

Table 11. How primary wood product producers handle hole/interior defect deductions by annual production level in the Appalachian region.

\begin{tabular}{rrrrrrr}
\hline Prod Level & Response & Neither & Length & Diameter & Both & Total \\
\hline \multirow{2}{*}{1} & Observed & 3 & 11 & 9 & 8 & 31 \\
& Expected & 3.37 & 8.42 & 7.75 & 11.46 & \\
2 & Observed & 1 & 7 & 7 & 15 & 30 \\
Expected & 3.26 & 8.15 & 7.50 & 11.09 & \\
& Observed & 6 & 7 & 7 & 11 & 31 \\
Expected & 3.37 & 8.42 & 7.75 & 11.46 & \\
& Total & $\mathbf{1 0}$ & $\mathbf{2 5}$ & $\mathbf{2 3}$ & $\mathbf{3 4}$ & $\mathbf{9 2}$ \\
\hline${ }^{*} a \leq 0.05 \cdot \mathrm{P}<0.269$ & & & & &
\end{tabular}

A total of 35 (38.8\%) mills used both diameter and length when making deductions for shake, followed by $24(26.6 \%)$ that used a length deduction. Nineteen respondents $(21.1 \%)$ used only a diameter deduction and twelve (13.3\%) indicated they did not use any kind of diameter or 
length deduction (Table 12). Other rule of thumb deductions were made from visual assessments of the loss of board footage caused by the defect. No statistical relationship was noted between the deductions based on shake and annual mill production $(\mathrm{T}=10.22, \mathrm{P}<0.116)$.

Table 12. How primary wood product producers handle shake deductions by annual production level in the Appalachian region.

\begin{tabular}{rrrrrrr}
\hline Prod Level & Response & Neither & Length & Diameter & Both & Total \\
\hline \multirow{2}{*}{1} & Observed & 3 & 10 & 8 & 9 & 30 \\
& Expected & 4.00 & 8.00 & 6.33 & 11.67 & \\
2 & Observed & 1 & 7 & 7 & 15 & 30 \\
& Expected & 4.00 & 8.00 & 6.33 & 11.67 & \\
\multirow{2}{*}{3} & Observed & 8 & 7 & 4 & 11 & 30 \\
& Expected & 4.00 & 8.00 & 6.33 & 11.67 & \\
& Total & $\mathbf{1 2}$ & $\mathbf{2 4}$ & $\mathbf{1 9}$ & $\mathbf{3 5}$ & $\mathbf{9 0}$ \\
\hline \multirow{2}{*}{ To }
\end{tabular}

Trim allowance, or the presence of a small amount of extra length beyond the target log length (e.g.; $8 \mathrm{ft}, 4$ inches) on logs, ensures that a mill can saw lumber full length and not be forced to trim lumber back a foot or more. For instance, a 10-foot log with no trim will not yield 10 feet of lumber, since there is no room for error during the milling operation. Once those boards are trimmed, they will likely be cut back to 8-foot or 9-foot lengths.

Of the mills sampled, 26 of 100 preferred 4 inches of trim, while 25 respondents reported using "Other" preferred lengths of trim ranging from 0 to 12 inches. Twenty-five preferred 6 inches of trim, while 24 respondents preferred a range between 4 and 6 inches (Table 13). A statistically significant relationship was noted between preferred trim allowance and annual production $(\mathrm{T}=14.35, \mathrm{P}<0.026)$. More size 1 mills than expected preferred other specified lengths of trim and more size 2 mill than expected preferred 4 inches of trim. Furthermore, fewer size 3 mill than expected preferred other specified trim lengths, while more than expected mill size 3 preferred 6 inches of trim. 
Table 13. Primary wood producers preferred trim allowance by annual production level in the Appalachian region.

\begin{tabular}{|c|c|c|c|c|c|c|c|}
\hline \multicolumn{2}{|c|}{ Production Level } & Response & 4 in. & 4-6 in. & 6 in. & Other & Total \\
\hline \multirow{2}{*}{1} & Observed & & 6 & 5 & 6 & $14 *$ & 31 \\
\hline & Expected & & 8.06 & 7.44 & 7.75 & 7.75 & \\
\hline \multirow{2}{*}{2} & Observed & & $13^{*}$ & 8 & 7 & 7 & 35 \\
\hline & Expected & & 9.10 & 8.40 & 8.75 & 8.75 & \\
\hline \multirow{3}{*}{3} & Observed & & 7 & 11 & $12^{*}$ & $4 *$ & 34 \\
\hline & Expected & & 8.84 & 8.16 & 8.50 & 8.50 & \\
\hline & Total & & 26 & 24 & 25 & 25 & 100 \\
\hline
\end{tabular}

If the preferred trim allowance was not included in the log length, respondents were asked at what minimum trim allowance would the mill initiate a scale-based length deduction. Of the mills sampled, 30 (32.3\%) would make a length deduction at 2 inches of trim (Table 14). Nineteen respondents (20.4\%) made deductions based on other criteria. The remainder of the responses were based on differing lengths of trim. The chi-square test of independence showed no statistical relationship between the deductions based on minimum trim allowance and annual mill production $(\mathrm{T}=12.38, \mathrm{P}<0.135)$.

Table 14. Primary wood product producers minimum trim allowance by annual production level for the Appalachian region.

\begin{tabular}{llrrrrrr}
\hline Prod Level & Response & $\mathbf{1}$ in. & $\mathbf{2}$ in. & $\mathbf{3}$ in. & $\mathbf{4}$ in. & Other & Total \\
\hline \multirow{3}{*}{1} & observed & 6 & 5 & 3 & 5 & 8 & 27 \\
& expected & 5.23 & 8.71 & 3.19 & 4.35 & 5.52 & \\
2 & observed & 5 & 16 & 3 & 2 & 8 & 34 \\
& expected & 6.58 & 10.97 & 4.02 & 5.48 & 6.95 & \\
3 & observed & 7 & 9 & 5 & 8 & 3 & 32 \\
& expected & 6.19 & 10.32 & 3.78 & 5.16 & 6.54 & \\
& Total & $\mathbf{1 8}$ & $\mathbf{3 0}$ & $\mathbf{1 1}$ & $\mathbf{1 5}$ & $\mathbf{1 9}$ & $\mathbf{9 3}$ \\
\hline
\end{tabular}

${ }^{*} a \leq 0.05 \cdot \mathrm{P}<0.135$

\section{Grading Protocols}

Grading hardwood logs is a process that uses the exterior features of logs to determine quality. Generally, the log is divided into 4 quadrants or faces, then these faces are evaluated independently of one another to determine the presence or absence of defects. The grade is then 
based on the number of clear (i.e., defect free) faces. Several questions were asked of respondents regarding their grading procedures.

Of the mills sampled, 95 of 107 (88.7\%) graded logs without rolling the log to examine all four sides/faces (Table 15). Rolling logs is a common practice in the purchase or evaluation of veneer logs, but according to respondents, this is not the case with sawlogs. A large part of the reason is probably associated with saving time in a production setting where time is of the essence in getting loads of logs graded as quickly as possible. The chi-square test of independence showed no significant statistical relationship between level of production and grading logs as they lay $(\mathrm{T}=1.84, \mathrm{P}<0.339)$.

Table 15. Do primary wood product producers grade logs as they lay by production level in the Appalachian region?

\begin{tabular}{clrrr}
\hline Prod Level & Response & No & Yes & Total \\
\hline \multirow{2}{*}{1} & Observed & 6 & 29 & 35 \\
& Expected & 3.93 & 31.07 & \\
2 & Observed & 3 & 34 & 37 \\
& Expected & 4.15 & 32.85 & \\
3 & Observed & 3 & 32 & 35 \\
& Expected & 3.93 & 31.07 & \\
& Total & $\mathbf{1 2}$ & $\mathbf{9 5}$ & $\mathbf{1 0 7}$ \\
\hline
\end{tabular}

The respondents who answered that they do not roll logs were further asked about the assumptions made regarding the downside (hidden) face of the log. Of the mills sampled, 34 (42.5\%) assumed the downside of the log was "similar to other 3 sides", followed by "clear" with $27(33.8 \%)$ responses (Table 16). Assuming the face is "clear" often is a false assumption that unfairly boosts the quality of a particular log. Other responses included the downward face has at least one defect or more or half of the logs have defects on the downward face. No significant statistical relationship was noted $(\mathrm{T}=2.22, \mathrm{P}<0.696)$. 
Table 16. Assumption made about the down side of the log when grading hardwood sawlogs by annual production level for primary wood product producers in the Appalachian region.

\begin{tabular}{rlcccc}
\hline \multicolumn{2}{c}{ Prod Level } & Clear & Similar to other 3 sides & Other & Total \\
\hline \multirow{2}{*}{1} & Observed & 7 & 8 & 8 & 23 \\
& Expected & 7.76 & 9.78 & 5.46 & \\
2 & Observed & 11 & 14 & 6 & 31 \\
& Expected & 10.46 & 13.18 & 7.36 & \\
\multirow{2}{*}{3} & Observed & 9 & 12 & 5 & 26 \\
& Expected & 8,78 & 11.05 & 6.17 & \\
& Total & $\mathbf{2 7}$ & $\mathbf{3 4}$ & $\mathbf{1 9}$ & $\mathbf{8 0}$ \\
\hline
\end{tabular}

Finally, mills were asked if they would support the development of a standard log grading system. Of the mills that responded, $58(65.9 \%)$ indicated they would support an industry standard log grading system (Table 17). The chi-square test of independence showed no statistical relationship between the level of support for an industry standard log grading system and annual mill production $(\mathrm{T}=0.5, \mathrm{P}<0.778)$. That is, mill size does not seem to play a role in whether a mill would support the introduction of a standardized log grading system.

Table 17. Would primary wood product producers support an industry standard by annual production level for the Appalachian region.

\begin{tabular}{clllc}
\hline Prod Level & & No & Yes & Total \\
\hline \multirow{2}{*}{1} & Observed & 9 & 20 & 29 \\
& Expected & 9.89 & 19.11 & 31 \\
2 & Observed & 10 & 21 & \\
& Expected & 10.57 & 20.43 & 28 \\
& Observed & 11 & 17 & $\mathbf{8 8}$ \\
\hline
\end{tabular}

$* a \leq 0.05 \cdot \mathrm{P}<0.778$

\section{$\underline{\text { Factors Influencing Production }}$}

Several questions were asked in the survey about the form and level of total annual supply of raw material that producers purchase and if the respondents understood the real costs of running the mill. 
Mills were first asked if they purchase gate wood. Gate wood is defined as raw material (logs) purchased from an independent logger or wood broker where the seller is responsible for the transportation of the logs to the mill. Of the 108 responding mills, 94 or (87\%) indicated that gatewood purchase is a normal log acquisition process across all production level classes. A chisquare test of independence showed a statistical relationship between the purchase of gatewood and annual mill production $(\mathrm{T}=13.16, \mathrm{P}<0.001)$. That is, more mill size 1 than expected responded they did not purchase gatewood and fewer than expected mill size 3 responded they did not purchase gatewood (Table 18).

Table 18. Do primary wood product producers purchase gate wood by production level in the Appalachian region?

\begin{tabular}{rlrrc}
\hline Prod Level & No & Yes & Total \\
\hline \multirow{2}{*}{1} & Observed & $10^{*}$ & 23 & 33 \\
& Expected & 4.28 & 28.72 & 37 \\
2 & Observed & 3 & 34 & 38 \\
Expected & 4.80 & 32.20 & \\
\multirow{2}{*}{3} & Observed & $1^{*}$ & 37 & $\mathbf{1 0 8}$ \\
Expected & 4.93 & 33.07 & $\mathbf{9 4}$ \\
Total & $\mathbf{1 4}$ & &
\end{tabular}

$* a \leq 0.05 \cdot *$ Statistically significant at $0.05 a \leq \cdot \mathrm{P}<0.001$.

To further understand the level at which mills consume gatewood, responding mills were asked to detail how much of their total annual raw material supply is acquired through the purchase of gatewood. From the results, 44 of 100 (44\%) primary wood product producers reported they consume $0-25 \%$ of their annual raw material supply in gatewood. Furthermore, 56 of the 100 mills consume more than $25 \%$ up to $100 \%$ or $(56 \%)$ of their annual raw material supply in gatewood. No significant statistical relationship existed between annual level of gatewood supplies and annual production $(\mathrm{T}=3.12, \mathrm{P}<0.537)$ (Table 19). From this chi-square test of independence the groups had to be merged from four to three due to $25 \%$ of the cell counts being less than five. 
Table 19. Primary wood product producers annual supply of gatewood by production level in the Appalachian region.

\begin{tabular}{|c|c|c|c|c|}
\hline $\begin{array}{l}\text { Present Supply of Gatewood } \\
\text { Production Level }\end{array}$ & $>0$ and $\leq 25 \%$ & $>25 \%$ to $\leq 60 \%$ & $>60 \%$ & Total \\
\hline Observed & 14 & 4 & 11 & 29 \\
\hline Expected & 12.76 & 6.96 & 9.28 & \\
\hline Observed & 14 & 9 & 12 & 35 \\
\hline Expected & 15.40 & 8.4 & 11.20 & \\
\hline Observed & 16 & 11 & 9 & 36 \\
\hline Expected & 15.84 & 8.64 & 11.52 & \\
\hline Total & 44 & 24 & 32 & 100 \\
\hline
\end{tabular}

To better understand where mills are applying their specification sheets, mills were asked if they grade logs from their own stumpage tracts. The results showed that 64 of the $108(59.2 \%)$ mills did grade logs from purchased tracts (Table 20). The chi-square test of independence between level of production and if mills grade logs from their own stumpage tracts $(\mathrm{T}=2.27, \mathrm{P}$ $<0.322$ ) showed no significant statistical relationship.

Table 20. Do primary wood product producers grade logs from their own stumpage tracts by production level in the Appalachian region.

\begin{tabular}{rrrrr}
\hline Production Level & No & Yes & Total \\
\hline \multirow{2}{*}{1} & Observed & 17 & 17 & 34 \\
& Expected & 13.85 & 20.15 & 37 \\
2 & Observed & 15 & 22 & \\
Expected & 15.07 & 21.93 & 37 \\
\multirow{2}{*}{3 Observed } & 12 & 25 & \\
Expected & 15.07 & 21.93 & $\mathbf{1 0 8}$ \\
& Total & $\mathbf{4 4}$ & $\mathbf{6 4}$ &
\end{tabular}

In some cases, the mill desires to control the merchandising of logs, so mills will purchase raw material as tree length stems. In this type of procurement action, the logs are hauled as treelength pieces (usually to a top diameter that reflects the minimum diameter accepted by the mill for sawing) and then bucked and merchandised at the mill. Of the mills responding, 86 of 108 (79.6\%) indicated they did not purchase tree length stems. Furthermore, 
of the 22 mills that reported the purchase of tree length stems, 13 were from PA, OH, and WV. PA had 6 mills that purchased tree length stems, OH had 4, and WV had 3 mills. A statistical relationship was noted between the purchase of tree length stems and annual mill production ( $\mathrm{T}$ $=10.08, \mathrm{P}<0.006$ ), where fewer mill size 1 than expected did not purchase tree length stems and more than expected mill size 3 did purchase tree length stems. Furthermore, fewer than expected mill size 3 did not purchase tree length stems (Table 21).

Table 21. Do primary wood product producers buy tree length stems by production level in the Appalachian region.

\begin{tabular}{rrrcr}
\hline Production Level & No & Yes & Total \\
\hline \multirow{2}{*}{1} & Observed & 31 & $3^{*}$ & 34 \\
& Expected & 27.07 & 6.93 & 36 \\
2 & Observed & 31 & 5 & \\
Expected & 28.67 & 7.33 & 38 \\
Observed & $24^{*}$ & $14^{*}$ & \\
Expected & 30.26 & 7.74 & $\mathbf{1 0 8}$ \\
Total & $\mathbf{8 6}$ & $\mathbf{2 2}$ & \\
\hline
\end{tabular}

${ }^{*} a \leq 0.05 \cdot{ }^{*}$ Statistically significant at $0.05 \cdot \mathrm{P}<0.006$.

To further understand the extent to which mills consume tree length stems as raw material, respondents were asked how much of their annual raw material supply was obtained from tree length stems. Of the 86 responding mills, 63 (73.2\%) indicated that tree length stems comprise $0-25 \%$ of their annual raw material supply while 14 mills reported at least half of their annual raw material supply is obtained from tree length deliveries. No statistical relationship was noted between the total annual supply of tree length stems and level of annual production $(\mathrm{T}=$ 10.37, $\mathrm{P}<0.11$ ) (Table 22).

Table 22. Primary wood product producers supply of tree length stems by production level in the Appalachian region.

\begin{tabular}{|c|c|c|c|c|c|}
\hline $\begin{array}{l}\text { \% of tree length stems } \\
\text { Production Level }\end{array}$ & $\begin{array}{l}>0 \text { and } \\
\leq 25 \%\end{array}$ & $\begin{array}{l}>25 \%- \\
\leq 50 \%\end{array}$ & $\begin{array}{r}>50 \% \\
+\leq 75 \%\end{array}$ & $>75 \%$ & Total \\
\hline Observed & 19 & 3 & 0 & 1 & 23 \\
\hline Expected & 16.85 & 2.14 & 1.07 & 2.94 & \\
\hline Observed & 20 & 3 & 1 & 8 & 32 \\
\hline Expected & 23.44 & 2.98 & 1.49 & 4.09 & \\
\hline \multirow{3}{*}{$\begin{array}{l}\text { Observed } \\
\text { Expected } \\
\text { Total }\end{array}$} & 24 & 2 & 3 & 2 & 31 \\
\hline & 22.71 & 2.88 & 1.44 & 3.97 & \\
\hline & 63 & 8 & 4 & 11 & 86 \\
\hline
\end{tabular}


$* a \leq 0.05 \cdot \mathrm{P}<0.11$

When mills were asked if they had difficulty getting longer length logs, of the 107 responding mills, 82 (76.6\%) reported having no issues getting logs 14 feet to 16 feet in length. No statistical relationship existed between mills having difficulty getting longer length logs and level of annual production $(\mathrm{T}=1.4, \mathrm{P}<0.498)$ (Table 23).

Table 23. Do primary wood product producers have difficulty getting long length logs by production level in the Appalachian region?

\begin{tabular}{rlrrr}
\hline Prod Level & No & Yes & Total \\
\hline \multirow{2}{*}{1} & Observed & 27 & 6 & 33 \\
& Expected & 25.29 & 7.71 & 37 \\
2 & Observed & 29 & 8 & \\
Expected & 28.36 & 8.64 & 37 \\
Observed & 26 & 11 & \\
Expected & 28.36 & 8.64 & $\mathbf{1 0 7}$ \\
& Total & $\mathbf{8 2}$ & $\mathbf{2 5}$ &
\end{tabular}

The respondents were asked to indicate if they were paying any premiums for longer length logs. Of the 78 responding mills, 48 (61.5\%) indicated that no premiums were being paid for long length logs, while 30 mills reported that they did pay premiums for longer length logs. No statistical relationship was noted between mills paying premiums for longer length logs and level of annual production $(\mathrm{T}=0.14, \mathrm{P}<0.933)$ (Table 24).

Table 24. Are primary wood product producers paying premiums for longer length logs by production level in the Appalachian region?

\begin{tabular}{rrrrc}
\hline Prod Level & No & Yes & Total \\
\hline \multirow{2}{*}{1} & Observed & 13 & 7 & 20 \\
& Expected & 12.31 & 7.69 & 30 \\
2 & Observed & 18 & 12 & \\
& Expected & 18.46 & 11.54 & 28 \\
3 & Observed & 17 & 11 & \\
Expected & 17.23 & 10.77 & $\mathbf{7 8}$ \\
\hline
\end{tabular}


Straight through pricing is a purchasing strategy used by mills when placing a logger on contract. The term "straight through pricing" refers to a set price per thousand board feet delivered to the mill, based on a minimum scaling diameter and a minimum number of clear faces. For instance, the mill would pay the same price per mbf for logs 12 -inches DIB and up and having at least 2 clear faces. The mills were asked to indicate if they offer straight through pricing to loggers and, of the 107 responding mills, 57 (53.2) indicated they did not (Table 25). No statistical relationship existed between mills providing straight through pricing and level of annual production $(\mathrm{T}=5.53, \mathrm{P}<0.063)$.

Table 25. Do primary wood product producers provide straight through pricing by production level in the Appalachian region.

\begin{tabular}{rlrrr}
\hline Prod Level & No & Yes & Total \\
\hline \multirow{2}{*}{1} & Observed & 21 & 12 & 33 \\
& Expected & 17.58 & 15.42 & 37 \\
2 & Observed & 22 & 15 & \\
& Expected & 19.71 & 17.29 & 37 \\
3 & Observed & 14 & 23 & \\
Expected & 19.71 & 17.29 & $\mathbf{1 0 7}$ \\
\hline
\end{tabular}

$* a \leq 0.05 \cdot \mathrm{P}<0.063$

As the price of raw material has risen, it has become more important to understand the real cost to operate sawmills. When respondents were asked if they knew the cost to operate their mill per hour, 79 of the 105 (75.2\%) responding mills reported they did. No statistical relationship was noted between mills knowing the cost to run the mill per hour and level of annual production $(\mathrm{T}=0.79, \mathrm{P}<0.673)$ (Table 26). 
Table 26. Do primary wood product producers know the cost to run the mill per hour by production level in the Appalachian region?

\begin{tabular}{crrc}
\hline Prod Level & No & Yes & Total \\
\hline \multicolumn{1}{c}{ Observed } & 10 & 23 & 33 \\
Expected & 8.17 & 24.83 & 36 \\
2 Observed & 8 & 28 & 36 \\
Expected & 8.91 & 27.09 & \\
Observed & 8 & 28 & $\mathbf{1 0 5}$ \\
Expected & 8.91 & 27.09 & \\
\hline
\end{tabular}

${ }^{*} a \leq 0.05 \cdot \mathrm{P}<0.673$

To further investigate the understanding of the real cost of production, respondents were asked if they knew the sawing cost per mbf by species. Of the 103 responding mills, 67 (65\%) responded they did know the sawing cost per mbf by species. No statistical relationship was noted between mills knowing the sawing cost per mbf by species and level of annual production $(\mathrm{T}=2.72, \mathrm{P}<0.257)$ (Table 27).

Table 27. Do primary wood product producers know the sawing cost per mbf by species by production level in the Appalachian region?

\begin{tabular}{crrc}
\hline Prod Level & No & Yes & Total \\
\hline Observed & 15 & 18 & 33 \\
Expected & 11.53 & 21.47 & 36 \\
2 Observed & 12 & 24 & \\
Expected & 12.58 & 23.42 & 34 \\
Observed & 9 & 25 & \\
Expected & 36 & 67 & $\mathbf{1 0 3}$ \\
Total & $\mathbf{3 6}$ & $\mathbf{6 7}$ &
\end{tabular}

A chi-square test of independence was conducted to further understand the relationship of mills knowing the cost per hour to run the mill and sawing cost per species by mbf (Table 28). Of the responding mills, 61 of 103 (59.2\%) responded they know the cost of both, while 19 of the 103 did not know the cost of either. The chi-square test of independence showed no statistical relationship existed between the two variables $(\mathrm{T}=5.12, \mathrm{P}<0.527)$. 
Table 28. Do primary wood product producers know the cost to run the mill per hour and the sawing cost per mbf by species delineated by production level in the Appalachian region?

\begin{tabular}{rlrrrrr}
\hline Prod Level & Neither & $\begin{array}{c}\text { Just cost } \\
\text { per hour }\end{array}$ & \multicolumn{2}{c}{$\begin{array}{c}\text { Just cost per } \\
\text { species by MBF }\end{array}$} & Both & Total \\
\hline \multirow{2}{*}{1} & Observed & 8 & 2 & 7 & 16 & 33 \\
& Expected & 6.09 & 1.92 & 5.45 & 19.5 & \\
2 & Observed & 5 & 3 & 7 & 21 & 36 \\
& Expected & 6.64 & 2.1 & 5.94 & 21.3 & \\
& Observed & 6 & 1 & 3 & 24 & 34 \\
& Expected & 6.27 & 1.98 & 5.61 & 20.1 & \\
& Total & $\mathbf{1 9}$ & $\mathbf{6}$ & $\mathbf{1 7}$ & $\mathbf{6 1}$ & $\mathbf{1 0 3}$ \\
\hline${ }^{*} a \leq 0.05 \cdot \mathrm{P}<0.527$ & & & & &
\end{tabular}

$\underline{\text { Specification Sheet Analysis }}$

Specification sheets are used by mills to convey how they asses the value of sawlogs.

Mills often make specification sheets available to the public, detailing log grades and associated pricing. Respondents were asked if their log specification sheets are publicly available, with the most common response being "No" with 63 (62.4\%) of responses.

A chi-square test of independence was performed to evaluate the relationship between level of production and whether wood product producers have a publicly available specification sheet. The results indicated that a different statistical relationship exists between the highest production mills and the lower production mills $\left(\mathrm{X}^{2}=7.44, \mathrm{P}<0.024\right)$ (Table 29). That is, more high production mills are likely to have a publicly available written log grading standard.

Table 29. Do primary wood product producers have publicly available log grading standards by annual production level for the Appalachian region.

\begin{tabular}{rlrrr}
\hline \multicolumn{1}{l}{ Prod Level } & & No & Yes & Total \\
\hline \multirow{2}{*}{1} & Observed & 23 & $8^{*}$ & 31 \\
& Expected & 19.34 & 11.66 & \\
2 & Observed & 25 & 11 & 36 \\
& Expected & 22.46 & 13.54 & 34 \\
3 & Observed & $15^{*}$ & $19^{*}$ & \\
& Expected & 22.21 & 12.79 & $\mathbf{1 0 1}$ \\
\hline
\end{tabular}

${ }^{*} a \leq 0.05{ }^{*}$ Statistically significant at $0.05 \mathrm{P}<0.024$. 
A total of 26 specification sheets were returned with the survey. These documents generally specified log grade based on clear faces/sides and scaling diameter. An analysis of these specification sheets was undertaken to determine if there was any consistency among and between the responding mills relative to the actual grading processes defined in each specification sheet. This process was completed for each specification sheet and the results are contained in (Table 30).

Table 30. Distribution of the highest log grade across scaling diameter and clear faces, based on specification sheets provided by survey respondents from primary wood product producers in the Appalachian region $(\mathrm{N}=26)$.

\begin{tabular}{lccccc}
\hline & \multicolumn{5}{c}{ Clear Faces } \\
Diameter & $\mathbf{4}$ & $\mathbf{3}$ & $\mathbf{2}$ & $\mathbf{1}$ & $\mathbf{0}$ \\
\hline 18 in. & 26 & 6 & 0 & 0 & 0 \\
17 in. & 20 & 5 & 0 & 0 & 0 \\
16 in. & 18 & 5 & 0 & 0 & 0 \\
15 in. & 9 & 4 & 0 & 0 & 0 \\
14 in. & 4 & 2 & 0 & 0 & 0 \\
13 in. & 1 & 0 & 0 & 0 & 0 \\
12 in. & 1 & 0 & 0 & 0 & 0 \\
11 in. & 0 & 0 & 0 & 0 & 0 \\
10 in. & 0 & 0 & 0 & 0 & 0 \\
9 in. & 0 & 0 & 0 & 0 & 0 \\
8 in. & 0 & 0 & 0 & 0 & 0 \\
\hline
\end{tabular}

Based on the matrix provided in Table 30, prime log grades can start at 12 inches diameter with 4 clear faces or 14 inches diameter with 3 clear faces. Thus, any log with a small end diameter greater than 12 inches and 4 clear faces or 14 inches and 3 clear faces was valued the same per $m b f$ as a log with a diameter of 18 inches and 4 clear faces, even though the yield of high quality boards generally increases in larger diameter classes and with increasing number of clear faces.

The same process was applied to the second highest grade as detailed in the individual mill specification sheets, with the results displayed in Table 31. The most common combination of diameters and clear faces is 15 inches and 4 clear faces (Table 31). 
Table 31. Distribution of the second highest log grade across scaling diameter and clear faces, based on specification sheets provide by survey respondent from primary wood product producers in the Appalachian region $(\mathrm{N}=\mathbf{2 6})$.

\begin{tabular}{lrrrrr}
\hline $\begin{array}{l}\text { Diameter } \\
\text { (inches) }\end{array}$ & \multicolumn{5}{c}{ Clear Faces } \\
\hline 18 in. + & $\mathbf{4}$ & $\mathbf{3}$ & $\mathbf{2}$ & $\mathbf{1}$ & $\mathbf{0}$ \\
17 in. & 0 & 9 & 3 & 0 & 0 \\
16 in. & 5 & 10 & 2 & 0 & 0 \\
15 in. & 8 & 10 & 2 & 0 & 0 \\
14 in. & 15 & 9 & 1 & 0 & 0 \\
13 in. & 13 & 10 & 1 & 0 & 0 \\
12 in. & 7 & 6 & 1 & 0 & 0 \\
11 in. & 6 & 4 & 0 & 0 & 0 \\
10 in. & 0 & 1 & 0 & 0 & 0 \\
9 in. & 0 & 1 & 0 & 0 & 0 \\
8 in. & 0 & 0 & 0 & 0 & 0 \\
\hline
\end{tabular}

The second highest log grade has a large diameter range and can contain a range of clear faces, from 2 to 4 . This second highest log grade is quite variable and makes the possibility for fair pricing impossible due to the variability of the log characteristics that qualify. Where a grade could start at 13 inches in diameter and only have 2 clear faces, the exact same grade at another mill could apply to a $\log 17$ inches in diameter and four clear faces. This wide range of specifications defining log value has hindered the industry and produced uncertainty in developing consistent values for hardwood logs.

The analysis of these specification sheets revealed a significant degree of variation in how mills categorize their two highest log grades, with significant overlap between log grades. This circumstance has served to create confusion for log sellers as they try to maximize the value of their logs.

One important factor to keep in mind from this analysis is the geographic range from which these specification sheets originate. Geographical location can influence the species mix of a particular region and possibly change the criteria defining the log grades due to the quality of timber and markets associated with that region. 


\section{Conclusions}

The literature review developed for this study suggests that the industry has attempted to standardize hardwood log grading at different times over the last 100 years. A total of 23 documents pertaining to log grading were identified through this review and 19 of the documents described different log grading systems. These systems were based on both theoretical and empirical data. The majority of these log grading systems defined three to four distinct $\log$ grades, but some had as many as six. Most of these systems used International $1 / 4$ inch or Doyle $\log$ rule to determine volume.

Unfortunately, primary wood product producers in the Appalachian region never really adopted any of these log grading systems for their raw material purchases. Furthermore, the research community has produced nothing in the way of standardization since the late 1960's. This has encouraged the evolution of ad hoc log grading systems within the industry, creating a lack of standardization.

A number of conclusions can be drawn from this study. First, each responding mill or yard that purchases logs has a different way of grading and scaling, based on their own interests and experience. The analysis of specification sheets illustrates this very well, in that a mill's highest grade log can vary over a wide range of diameters and clear faces. However, some basic commonalities do exist among and between hardwood mills in the Appalachian region. Three basic components serve as the basis for grading and scaling logs: species, scaling diameter, and clear faces and is applicable over all mill production sizes.

Apart from these basic commonalities there is very little to suggest any type of standardization. And, while these three components form a solid base for the development of a standard log grading and scaling system, other necessary components must be developed from the more common approaches reported in the survey or, where possible, include more than one option for particular components. Permitting more than one option occurs in the case of specifying a standard log rule for volume determination. The Doyle log rule was far and away the most common log rule in use. But in order for a standardized system to attain broad acceptance, all three log rules cited by respondents must be permitted (Doyle, Scribner, and International $1 / 4$ inch). Similarly, the option of buying both even and odd length logs must be included, even though a majority of mills (57.9 percent) purchased only even length logs. 
Further, with respect to log length, the issue of trim allowance again showed significant variation among respondents, with 4 inches or 4 - 6 inches being the most common. Similarly, the minimum trim allowance before applying a deduction was quite variable, from $1-4$ inches. With such variability, some further discussion among log grading practitioners will be required in order to reach a consensus about how to handle this important factor in a standardized system.

In the case of scaling diameter, the number of reported methods does not lead to a consensus among respondents. In this case, a method must be chosen that is relatively common but also does not favor the buyer or seller in any significant way. The best option would appear to be to measure the shortest diameter then rotate 90 degrees and take the second diameter measurement, then average them, which was actually the second most common response (31.4\%). The most common response was to measure the smallest diameter then the largest diameter and average them, which would tend to slightly favor the seller of logs, and would not be the best option for a standardized system.

Handling fractional portions of an average scaling diameter also resulted in a number of options reported by respondents. Perhaps the most logical approach is to simply decide how to handle a 0.5 fraction. For practical purposes, a rule that says round down if the fraction is $\leq 0.5$, round down and if the fraction is $>0.5$ round up. This approach establishes a level of consistency that does not require remembering to round up or down on the next log or favor the buyer by only rounding up if the fraction is $\geq 0.75$ inches.

When it comes to adjusting for defects such as double hearts, sweep, holes, and shake several options were identified by respondents. In the case of double hearts, nine different methods were reported and varied from a length deduction to adjusting scaling diameter in a number of ways. Since the survey question did not ask about deductions based on the severity of double hearts, it is probably reasonable to consider different adjustments based on the severity. This would consist of the existence of two distinct hearts, to the two distinct hearts containing a bark seam, and to the existence of some portion of the two stems representing the fork of the double heart.

For sweep, holes (interior defects), shake and other scaling defects like crook, splits, and spider shake respondents indicated that a common method for deduction is to take a diameter or length deduction for the log. For a standardized system, any scaling deduction must be in the form of a rule-of-thumb that can be applied quickly and efficiently in a production setting. The 
US Forest Service system used relatively complicated formulas for calculating percentage deductions for the various scaling defects, which was not conducive to production settings and was a significant drawback to adoption of the Forest Service rules. The survey was not designed to elicit specific rules of thumb being used by respondents, as that would have unduly complicated the response. The formulation of rules-of-thumb must necessarily take place apart from the survey results. The most reasonable approach is to analyze the log and lumber yield data of the AHC in such a way that the selection of a rule-of-thumb would not significantly alter the overrun/underrun expected from the log in the absence of the scaling defect.

From the grading perspective, a strong majority of mills do not roll the log when determining grade. Several assumptions about the downside of the log were contained in the responses, ranging from assuming the downside is clear to the downside is not clear and the downside is similar to the other three faces. This is perhaps the primary weakness of current log grading protocols used by the industry. Assumptions about what the log grader cannot see create a situation in which the quality of logs is much too variable, creating problems with how logs are priced and ultimately with mill economics.

The specification sheet analysis was specifically designed to determine the variation in how mills grade logs of different sizes and clear faces. The results illustrate that without a standardized system in place, the variation in how mills grade and scale their highest grade and second highest grade logs is significant. It also indicates a lack of thorough knowledge about the lumber grade yields a mill can expect to produce from logs of a given size and quality. Furthermore, and most importantly, it alone illustrates a need for a standardized system for log grading and scaling. Fortunately, nearly $66 \%$ of respondents recognized the need for such a standard when asked about whether they would support an industry standard for log grading and scaling and sets the stage for the AHC and the industry to pursue the creation of a standardize log grading and scaling system.

The other questions in the survey were focused primarily on developing and understanding how logs are procured and to what level the mills understand their cost structure, since sawing costs play a vital role in ultimately determining optimal pricing of logs.

From the procurement perspective, $87 \%$ of respondents purchased some proportion of their log furnish as gatewood, with the remainder presumably being a combination of controlled stumpage and from log yards. Also, a large percentage (80\%) buy only log length material. The 
remaining respondents purchasing tree-length stems have made the strategic decision to place the bucking of logs for grade in the hands of mill personnel and not loggers in the field. Anecdotal information has traditionally led many to believe that procuring longer length logs is a problem. However, survey respondents (77\%) indicated that is not a problem, although 38 percent were paying premiums for longer length logs.

Finally, straight through pricing was reported by $47 \%$ of respondents. The advantage of straight thru pricing is that the log inspection process is expedited at the mill and is much easier for a logger to implement. The downside is that pricing the logs is much more difficult in that the mill must estimate the proportion of each grade of $\log$ (which can vary from tract to tract) and then base pricing on the those proportions, which can have negative impacts on mill economics.

Finally, mills were asked about their costs per hour and by volume (mbf). Strong majorities said they knew their cost per hour (75\%) and their cost per MBF (65\%). Of great concern is that $18 \%$ do not seem to know their costs (either hourly or by MBF) and don't seem to be tracking those costs.

All of the factors reported and analyzed from this survey, taken together, confirm that the art and science of log grading and scaling is as variable as there are mills practicing grading and scaling. This has led sawmills to purchase raw material on a variety of platforms, leaving industry and log suppliers in an environment where it is difficult or near impossible to make intelligent economic decisions about where to sell their logs. A cornucopia of grading and scaling protocols among hardwood sawmills is not serving the overall best interests of the hardwood industry.

Based on the results of this study, a standardized hardwood log grading system is sorely needed. The basic elements of a standardized system are that it must be simple to use in a production setting and that these elements actually mirror what the industry is currently using, and ultimately serve as the basis for efficiently pricing hardwood logs. Log grades must be based on extensive empirical data which will be collected on "per log" basis. The grades would necessarily be based on lumber yields of NHLA lumber grades, which relate back to scaling diameter and number of clear faces. Then, combining log grade with overrun/underrun, sawing costs, and lumber/cant pricing, the pricing of logs can be consistently determined. 
Barriers are created when primary wood product producers are handed a variety of protocols.. In that case, it can difficult to extract the best optionfor producers, landowners, and contractors. The opinions of all interested stakeholders must be considered in order to insure actual implement and continued development of a standardized hardwood log grading system.

Developing a log grading standard ensures a transparent system that benefits landowners, loggers, and mill owners. Based on the results of this study, several recommendations can be made to advance the development and implementation of a national and regional hardwood log grading system:

1. The continued efforts of the AHC to collect and analyze individual logs to determine lumber grade yields that also incorporate overrun/underrun values are essential in establishing log grades that are logical and differentiate between logs of varying diameter and quality. As such, the continued collection of empirical data is the necessary component to eventually establishing a standardized system.

2. A new, standardized system that will be acceptable to industry must come about in collaboration with one or more industry associations. In this way, development, promotion, and implementation does not arise solely from a public entity, but rather has the imprimatur of as industry association.

3. In the process of developing a standardized system, an effort must be made to include industry representatives, including on the ground practitioners, in discussions about how to best structure the system. 


\section{$\underline{\text { Literature Cited }}$}

1. Anonymous: Hardwood Sawlog Classification Guidelines. Queensland Department of Industry (DPI) Forestry., October, $2001 \sim 39$ pp.

2. Avery, T. E., and Burkhart H. E. 1983. Forest measurements third edition. McGraw-Hill series in forest resources. $331 \mathrm{pp}$.

3. Benson, A.O., and A.C. Wollin. 1938. Grading Hardwood Logs. Project L-260-2, Working Plan. USDA Forest Service, For. Prod. Lab. 15 pp.

4. Benson, A.O. 1941. Something new in hardwood log grades. Journal of Forestry 39(1):1315.

5. Benson, A.O. and A. C. Wollin. 1941. Grading northern hardwood logs. US Dept. Agriculture Forest Service Report. November, 1941. 34 pp.

6. Boone, H. Interview by J. Thompson. Personal communication, South agricultural science building. West Virginia University.

7. Bryant, C. B. 1913. Logging - The Principles and General Methods of Operation in the United States. John Wiley \& Sons, New York, NY. 547 pp.

8. Conover, W.J. 1980. Practical nonparametric statistics. John Wiley \& Sons, NY. 493 pp.

9. Chapman, H. H., 1921. Forest Mensuration., Yale University. New York John Wiley \& Sons. $522 \mathrm{pp}$.

10. Rast, E. D., Sonderman, D. L., Gammon, G .L. 1973. A guide to hardwood log grading. Gen. Tech. Rep. NE-1. Upper Darby, PA: U.S. Department of Agriculture, Forest Service, Northeastern Forest Experiment Station, $1973 \sim \sim 32$ p.

11. Freese, Frank., 1973. A Collection of Log Rules. Forest Products Laboratory Madison, WI. 65 pp.

12. Garver, R. D., and Raymond H. Miller. 1933. Lumber and log grades for southern hardwoods. Madison, Wis: U.S. Dept. of Agriculture, Forest Service, Forest Products Laboratory. 19 pp.

13. Graves, Henry Solon: Forest Mensuration. John Wiley and Sons, New York, 1906.488 pp.

14. Hassler C. C., Osborn, L. E., Grushecky, S. T., and McNeel, J. F. (2019) Hardwood Log Grading in the United States-Part II: United States Forest Service Log Grades and the Hardwood Industry. Forest Products Journal: 2019, Vol. 69, No. 2, pp. 124-130. 
15. Hassler, C.C. (2019). Interview by J. Thompson. Personal communication, Percival hall. West Virginia University.

16. Herrick, A. M. 1946. Grade yields and overrun from Indiana hardwood sawlogs. Purdue University Agricultural Experiment Station, Agr. Exp. Sta. Bul. 516. 60pp.

17. Herrick, A.M. 1949. How to grade hardwood sawlogs. Purdue University Agricultural Extension Service, Agr. Ext. Bull. 346. 8pp.

18. Kramer, P. R. 1952. Log Grade Classification Based on Standard Lumber Recovery for Inferior Upland Hardwoods in East Texas. Texas Forest Service, Forest Products Department, Lufkin,TX.Technical Report No. 4. 34pp.

19. Krejcie, R. V., and Morgan, D. W. 1970. Determining sample size for research activities. Educational and psychological measurement, Vol, 30. 610pp.

20. King, W. W. 1958. Evaluating Quality of Black Walnut Sawlogs. Forest Products Journal, September: 243-248 pp.

21. Lockard, C.R. 1957. Manual for hardwood log grading in the northeast (Preliminary edition). Northeastern Forest Experimental Station Forest Service, U.S. Dept. Agri. Upper Darby, PA. 41pp

22. Petro, F.J. 1962. How to Evaluate the Quality of Hardwood Logs for Factory Lumber. Forest Products Research Branch, Ottawa Laboratory, Ottawa. Canada.Technical Note No. 34. 33pp.

23. Ohio Forestry Association. 1965. Ohio standard saw log grades. Ohio Forestry Association, Inc., Columbus, OH. 8pp.

24. Anonymous: Report of The U. S. Forest Service Programs Resulting From the New England Hurricane of September 21, 1943. Northeastern Timber Salvage Administration. February 1943. Boston, Mass. 594 pp.

25. R Core Team (2019). R: A language and environment for statistical computing. R Foundation for Statistical Computing, Vienna, Austria. URL https://www.R-project.org/.

26. Schumacher, F.X., and H.E. Young. 1941. Empirical log rules according to species groups and lumber grades. Journal of Forestry 41(7):511-518.

27. USDA Forest Service. 1938. Pertinent Facts on Salvage of New England Timber. Northeastern Timber Salvage Administration. US. Dept. Agriculture Forest Service Report. R1183., November, $1938 \sim 31 \mathrm{pp}$.

28. USDA Forest Service. 1965. A Guide to Hardwood Log Grading. Northeastern Forest Experiment Station, Upper Darby, PA. 50pp. 
29. Vaughan, C.L., A.C. Wollin, K.A. McDonald, and E.H. Bulgrin. 1966. Hardwood log grades for standard lumber. U.S. Forest Service Research Paper FPL 63. 54pp.

30. Wallace, O.P. 1948. A simple method for grading hardwood logs and determining $\log$ values for New Hampshire. J. Forestry 46:377-379

31. Wallace, O.P. 1955. A simple method for grading hardwood logs. University of New Hampshire, Agricultural Experiment Station, Durham New Hampshire. Station Technical Bulletin 94. 7pp.

32. Wollin, A. C. and C. L.Vaughan. 1947. Sawlog Grades for Hardwoods - Central States Studies. USFS Forest Products Lab, Madison, WI, No. D1699. 22pp.

33. Wollin, A. C. and C. L. Vaughan. 1949. Hardwood Log Grades and Standard Lumber Proposals and Results. USDA Forest Service, Forest Products Lab, D1737. 15pp.

34. Wollin, A. C. and C. L. Vaughan. 1959. Hardwood Log Grades and Standard Lumber Proposals and Results (Information Reviewed and Reaffirmed). USDA Forest Service, Forest Products Lab, D1737. 15pp. 


\section{Appendix A: Survey}

\section{Sawmill Survey of Log Grading and Scaling Specifications}

1. What log rule are you using?

2. What's your annual lumber production?

3. Do you buy logs as gatewood? $\square$ Yes $\mid \square$ No

$\square$ Doyle

Scribner $\square$ International

What percentage of your log supply is gatewood?

4. Do you grade and scale logs from your own stumpage tracts?

5. Do you buy treelength logs at your yard?

Do you grade the logs bucked from treelength stems?

What percentage of your logs is from treelength stems?

6. Do you grade logs "as they lay"?

If so, what is the assumption about the down side of the log when you are grading?

7. Do you buy (accept) logs of odd lengths (9', 11', 13', 15') or just even lengths?

$\square$ Odd lengths and even lengths $\mid \square$ Just even lengths

8. How do you determine scaling diameter? For instance, short way only; short way then 90 degrees to that and average; or something else?

When averaging measurements of diameter, how do you round fractional portions? e.g., $<=0.5$ " round down, round up if $>=0.75 "$, etc. Please describe below:

9. How do you handle scaling diameter measurement of a double heart? Please describe below:

10. Do you have difficulty getting logs longer than 12 feet?

$\square$ Yes $\mid \square$ No

If yes, are you paying any premiums for longer length logs (for instance do you pay more for 14' and 16 ' logs)?

$\square$ Yes $\mid \square$ No

11. Do you pay differently for butt logs than upper logs with the same diameter and same number of clear faces?

$\square$ Yes $\mid \square$ No

12. Do you provide straight through pricing? For instance, paying the same $\$$ per MBF for logs of a minimum diameter and minimum clear faces. As an example, 12" and up and at least 2 clear faces.

13. How do you handle the following scaling defects when adjusting log scale?

Sweep?

$\square$ Rule-of-thumb deduction? | $\square$ Other

If Other, please specify:

If you use a Rule-of-thumb: Do you use a use a scaling diameter deduction?

Do you use a use a log length deduction?

Holes?

$\square$ Rule-of-thumb deduction?| $\square$ Other

If Other, please specify:

If you use a Rule-of-thumb: Do you use a use a scaling diameter deduction?

Do you use a log length deduction?

Shake?

$\square$ Rule-of-thumb deduction? $\square$ Other

If Other, please specify:

If you use Rule-of-thumb: Do you use a use a scaling diameter deduction?

Do you use a log length deduction?

14. What is your preferred trim allowance (in inches) for logs?

What is the minimum trim allowance (in inches) for a log before you make a length deduction?

15. Do you trim boards only to even lengths or to odd lengths as well? 


\section{$\square$ Odd lengths and even lengths $\mid \square$ Just even lengths}

16. Do you have a publicly available set of log grade specifications? $\quad \square$ Yes $\mid \square$ No If Yes, please include a copy of your publicly available log specification sheet with your survey response. The specifications and your survey will remain anonymous and only be used in aggregation with other mills to develop general log grading specifications.

17. Do you know what it costs per hour to run your mill? Do you know the sawing cost per MBF, by species?

18. Would you support an industry standard for grading and scaling hardwood sawlogs?

In case we have questions, who should we contact? Name:

Phone: Email:

If you have any questions about the survey, please contact JR Thompson at jrthompson1@mix.wvu.edu.

Please send completed survey to JF McNeel, WVU Appalachian Hardwood Center, P.O. Box 6125, Morgantown, WV 26506-6125 by for a drawing on a $\$ 100$ American Express Card 


\section{Appendix B: Benson and Wollin, 1941}

Grading northern hardwood logs

Table B1: Log Grades

(Benson and Wollin, 1941 p. 14)

\begin{tabular}{|c|c|c|c|c|c|}
\hline Log Grade & Log Length & $\begin{array}{l}\text { Log } \\
\text { Diameter }\end{array}$ & $\begin{array}{l}\text { Cull } \\
\text { Permitted }\end{array}$ & $\begin{array}{l}\text { Sweep } \\
\text { Permitted }\end{array}$ & $\begin{array}{l}\text { Surface } \\
\text { requirements } \\
\text { on each of } \\
\text { three faces of } \\
\text { log }\end{array}$ \\
\hline & & & \multicolumn{2}{|c|}{ Deduction from gross scale } & \\
\hline \multirow[t]{2}{*}{1} & \multirow[t]{2}{*}{$10^{\prime}+$} & $\begin{array}{l}12-15 " \\
\text { Logs under } \\
15 " \text { must be } \\
\text { butts }\end{array}$ & \multirow[t]{2}{*}{$40 \%$} & \multirow[t]{2}{*}{$15 \%$} & $\begin{array}{l}5 / 6 \text { yield in } \\
\text { cuttings not } \\
\text { less than } 7 \\
\text { long }\end{array}$ \\
\hline & & $16 "+$ & & & $\begin{array}{l}5 / 6 \text { yield in } \\
\text { not more than } \\
2 \text { cuttings not } \\
\text { less than } 5 \\
\text { long }\end{array}$ \\
\hline \multirow[t]{2}{*}{2} & $8^{\prime}$ and $9^{\prime}$ & $12 "+$ & \multirow[t]{2}{*}{$50 \%$} & \multirow[t]{2}{*}{$30 \%$} & $\begin{array}{l}3 / 4 \text { yield in not } \\
\text { more than } 2 \\
\text { cuttings not } \\
\text { less than } 3 \text { ' } \\
\text { long }\end{array}$ \\
\hline & $10^{\prime}+$ & $10 "+$ & & & $\begin{array}{l}\text { Logs under } \\
12 \text { ' long, } 2 / 3 \\
\text { yield in not } \\
\text { more than } 2 \\
\text { cuttings not } \\
\text { less than 3' } \\
\text { long; in logs } \\
12 \text { ' and over } \\
3 \text { cuttings } \\
\text { permitted }\end{array}$ \\
\hline 3 & $8^{\prime}+$ & \multirow[t]{2}{*}{$8 "+$} & \multirow[t]{2}{*}{$331 / 3$ sound } & \multirow[b]{2}{*}{$\begin{array}{l}\text { Not over } \\
\text { centered in } 8 \\
\text { in logs up to } \\
12 " \text { and 6" in } \\
\text { logs over } 12 "\end{array}$} & \multirow{2}{*}{$\begin{array}{l}\text { No } \\
\text { restrictions }\end{array}$} \\
\hline $3 \mathrm{~A}$ (ties) & $81^{1 / 2}$ or $17^{\prime}$ & & & & \\
\hline
\end{tabular}


Appendix C: Lockard, 1957

Manual for hardwood log grading in the northeast (Preliminary edition)

Table C1: Construction Grade

(Lockard, C.R., 1957 p.11)

\begin{tabular}{|c|c|c|}
\hline \multicolumn{2}{|c|}{ Specifications/Grade } & Construction \\
\hline \multicolumn{2}{|c|}{ Position in Tree } & Butt \& Upper \\
\hline \multicolumn{2}{|c|}{ Diameter, Small End } & $8 ”+$ \\
\hline \multicolumn{2}{|c|}{ Length, Without Trim } & 8 \\
\hline \multicolumn{2}{|c|}{ Clear Cuttings } & No Requirements \\
\hline \multicolumn{2}{|c|}{ Sweep Allowance, Absolute } & $1 / 4$ Diameter small end for each 8 ' of length \\
\hline \multirow{3}{*}{$\begin{array}{l}\text { Sound } \\
\text { Surface } \\
\text { Defects }\end{array}$} & Single Knots & $\begin{array}{l}\text { Any number, if no one knot has an average collar diameter in } \\
\text { excess of } 1 / 3 \text { of log diameter at point of occurrence. }\end{array}$ \\
\hline & Whorled Knots & $\begin{array}{l}\text { Any number, if sum of collar diameter does not exceed 1/3 of } \\
\qquad \log \text { diameter at point of occurrence. }\end{array}$ \\
\hline & Holes & $\begin{array}{c}\text { Any number provided none has a diameter over } 1 / 3 \text { of log } \\
\text { diameter at point of occurrence, and none extends over 3" into } \\
\text { included timber. }\end{array}$ \\
\hline \multicolumn{2}{|c|}{ Unsound Surface Defects } & $\begin{array}{l}\text { Same requirement as for sound defects if they extend into } \\
\text { including timber, no limit if they do not. }\end{array}$ \\
\hline \multirow[b]{2}{*}{$\begin{array}{c}\text { End } \\
\text { Defect }\end{array}$} & Sound & No requirements. \\
\hline & Unsound & $\begin{array}{c}\text { None Allowed; Must be sound internally, will admit } 1 \text { shake } \\
\text { not more than } 1 / 3 \text { width of a } 1 \text { split } 5 \text { " long (maximum) in } \\
\text { contained timber. }\end{array}$ \\
\hline
\end{tabular}


Appendix D: Lockard, 1957

Manual for hardwood log grading in the northeast (Preliminary edition)

Table D1: Local Use Grade

(Lockard, C.R., 1957 p.13)

\begin{tabular}{|c|c|c|}
\hline \multicolumn{2}{|c|}{ Specifications/Grade } & Local Use \\
\hline \multicolumn{2}{|c|}{ Position in Tree } & Butt \& Upper \\
\hline \multicolumn{2}{|c|}{ Diameter, Small End } & $8 "+$ \\
\hline \multicolumn{2}{|c|}{ Length, Without Trim } & 8 \\
\hline \multicolumn{2}{|c|}{ Sweep Allowance, Absolute } & $1 / 2$ Diameter of small end. \\
\hline \multicolumn{2}{|c|}{ Total Cull Allowed } & $50 \%$ \\
\hline \multicolumn{2}{|c|}{ Clear Cuttings } & No Requirements \\
\hline \multirow{2}{*}{$\begin{array}{l}\text { Surface } \\
\text { Defects }\end{array}$} & Sound & \multirow{2}{*}{$\begin{array}{l}\text { Only requirement is that diameter of knots, holes, rot, ECT., } \\
\text { Shall not exceed } 1 / 2 \text { diameter of log at point of occurrence. }\end{array}$} \\
\hline & Unsound & \\
\hline \multicolumn{2}{|c|}{ Sound End Defects } & No Requirements \\
\hline
\end{tabular}




\section{Appendix E: Vaughan, et al 1966}

Hardwood log grades for standard lumber

Table E1: Log Grades

(Vaughan, et al 1966 p. 4)

\begin{tabular}{|c|c|c|c|c|c|c|c|c|c|}
\hline \multirow{2}{*}{\multicolumn{2}{|c|}{$\begin{array}{l}\text { Grading Factors } \\
\text { Position in tree }\end{array}$}} & \multicolumn{3}{|c|}{ F1 } & \multicolumn{4}{|c|}{$\mathrm{F} 2$} & \multirow{3}{*}{$\begin{array}{l}\text { F3 } \\
\begin{array}{l}\text { Butts and } \\
\text { uppers }\end{array} \\
8 "+\end{array}$} \\
\hline & & Butts & Butts an & uppers & \multicolumn{4}{|c|}{ Butts and uppers } & \\
\hline \multicolumn{2}{|c|}{$\begin{array}{l}\text { Diameter, scaling, } \\
\text { minimum }\end{array}$} & ${ }^{1} 13-15 "$ & 16-19” & $20 ”+$ & \multicolumn{2}{|c|}{${ }^{2} 11 "$} & \multicolumn{2}{|c|}{$12 "+$} & \\
\hline \multicolumn{2}{|c|}{ Length, minimum } & \multicolumn{3}{|c|}{$10^{\prime}+$} & 10 & 8- & 10 & 12 & $8^{\prime}+$ \\
\hline \multirow{3}{*}{$\begin{array}{l}\text { Clear } \\
\text { cuttings } \\
\text { on each } 3 \\
\text { best faces }\end{array}$} & $\begin{array}{l}\text { Length } \\
\text { (minimum) }\end{array}$ & 7 ' & 5 & $3{ }^{\prime}$ & $3{ }^{\prime}$ & $3{ }^{\prime}$ & $3^{\prime}$ & 3 & $2 '$ \\
\hline & $\begin{array}{l}\text { Number on } \\
\text { face } \\
\text { (maximum) }\end{array}$ & 2 & 2 & 2 & 2 & 2 & 2 & 3 & No limit \\
\hline & $\begin{array}{l}\text { Fraction of } \\
\text { log length } \\
\text { required in } \\
\text { clear } \\
\text { cuttings }\end{array}$ & & $5 / 6$ & & $2 / 3$ & $3 / 4$ & $2 / 3$ & $2 / 3$ & $1 / 2$ \\
\hline \multirow{2}{*}{$\begin{array}{l}\text { Sweep and } \\
\text { Crook } \\
\text { allowance } \\
\text { (maximu } \\
\text { m)in } \\
\text { percent } \\
\text { gross } \\
\text { volume }\end{array}$} & $\begin{array}{l}\text { For logs } \\
\text { with less } \\
\text { than } 1 / 4 \text { of } \\
\text { end in } \\
\text { sound } \\
\text { defects }\end{array}$ & \multicolumn{3}{|l|}{$15 \%$} & \multicolumn{4}{|c|}{$30 \%$} & $50 \%$ \\
\hline & $\begin{array}{l}\text { For logs } \\
\text { with more } \\
\text { than } 1 / 4 \text { of } \\
\text { end in } \\
\text { sound } \\
\text { defects }\end{array}$ & \multicolumn{3}{|l|}{$10 \%$} & \multicolumn{4}{|c|}{$20 \%$} & $35 \%$ \\
\hline \multicolumn{2}{|c|}{$\begin{array}{l}\text { Total scaling deduction } \\
\text { including sweep and } \\
\text { crook }\end{array}$} & \multicolumn{3}{|l|}{$530 \%$} & \multicolumn{4}{|c|}{$650 \%$} & $50 \%$ \\
\hline \multicolumn{2}{|c|}{ End Defects } & \multicolumn{8}{|c|}{ See Instructions } \\
\hline \multicolumn{10}{|c|}{$\begin{array}{l}{ }_{1}^{1} \text { Ash and basswood butts can be } 12 \text { inches if otherwise meeting requirements for small No. } 1 \text { 's. } \\
2 \text { Ten-inch logs of all species can be No. } 2 \text { if otherwise meeting requirements for small No. } 1 \text { 's. } \\
{ }^{3} \text { A clear cutting is a portion of a face free of defects, extending the width of the face. } \\
{ }^{4} \text { See table } 46 \text { in Vaughan et al. (1966) } \\
5 \text { Otherwise No. } 1 \text { logs with } 41-60 \% \text { deductions can be No. } 2 \text {. } \\
{ }^{6} \text { Otherwise No. } 2 \text { logs with } 51-60 \% \text { deductions can be No. } 3 \text {. }\end{array}$} \\
\hline
\end{tabular}

